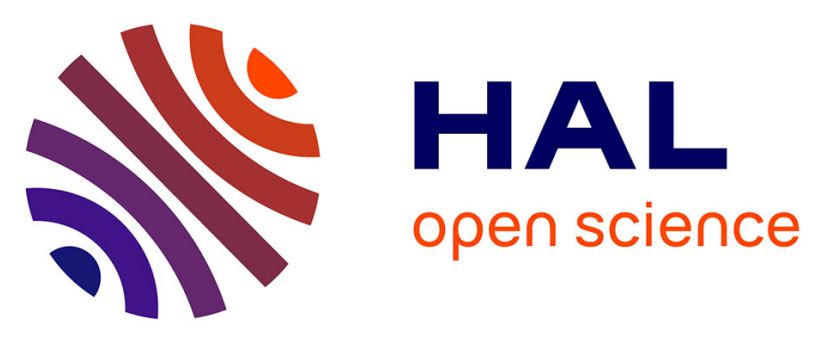

\title{
Synkinematic mafic/ultramafic sheeted intrusions: emplacement mechanism and strain restoration of the Permian Huangshan Ni-Cu ore belt (Eastern Tianshan, NW China)
}

Yannick Branquet, Charles Gumiaux, Stanislas Sizaret, Luc Barbanson, Bo

Wang, Dominique Cluzel, Guangrong Li, Arnaud de Launay

\section{To cite this version:}

Yannick Branquet, Charles Gumiaux, Stanislas Sizaret, Luc Barbanson, Bo Wang, et al.. Synkinematic mafic/ultramafic sheeted intrusions: emplacement mechanism and strain restoration of the Permian Huangshan Ni-Cu ore belt (Eastern Tianshan, NW China). Journal of Southeast Asian earth sciences, 2012, 56, pp.240-257. 10.1016/j.jseaes.2012.05.021 . insu-00708256

\section{HAL Id: insu-00708256 \\ https://hal-insu.archives-ouvertes.fr/insu-00708256}

Submitted on 9 Jul 2012

HAL is a multi-disciplinary open access archive for the deposit and dissemination of scientific research documents, whether they are published or not. The documents may come from teaching and research institutions in France or abroad, or from public or private research centers.
L'archive ouverte pluridisciplinaire HAL, est destinée au dépôt et à la diffusion de documents scientifiques de niveau recherche, publiés ou non, émanant des établissements d'enseignement et de recherche français ou étrangers, des laboratoires publics ou privés. 


\section{Synkinematic mafic/ultramafic sheeted intrusions: emplacement mechanism and strain restoration of the Permian Huangshan Ni-Cu ore belt (Eastern Tianshan, NW China)}

Yannick Branquet ${ }^{(1, *)}$, Charles Gumiaux ${ }^{(1)}$, Stanislas Sizaret ${ }^{(1)}$, Luc Barbanson ${ }^{(1)}$

Bo Wang ${ }^{(2)}$, Dominique Cluzel ${ }^{(3)}$, Guangrong Li ${ }^{(1)}$, Arnaud Delaunay ${ }^{(1)}$

1. Université d'Orléans / CNRS / INSU, ISTO - UMR 6113, Campus CNRS, 1A rue de la Férollerie, 45071 Orléans Cedex, France.

2. Department of Earth Sciences, Nanjing University, 210093, Nanjing, China.

3. Université de la Nouvelle-Calédonie Pole Pluridisciplinaire de la Matière et de l'Environnement EA 3325 BP R4, 98851 Nouméa Cedex, Nouvelle-Calédonie, France.

*Corresponding author: yannick.branquet@univ-orleans.fr 


\begin{abstract}
Whilst petrology, geochemistry and metal content of small mafic/ultramafic $\mathrm{Ni}-\mathrm{Cu}$ bearing complexes have been extensively studied, their structural controls and emplacement mechanisms are still poorly documented. This study addresses the last two points with the Huangshan $\mathrm{Ni}-\mathrm{Cu}$ ore belt (Chinese Eastern Tianshan) as a case study. The Huangshan intrusions are Early Permian; a period when the Tianshan orogenic belt recorded major rightlateral wrench tectonics, characterized by crustal-scale shear zones. Detailed mapping, petrostructural analysis and strain rate calculation within and around the intrusions allow us to establish that the Huangshan Ni-Cu-bearing mafic/ultramafic complexes are not layered intrusions. Instead, they emplaced by injection of several mafic/ultramafic magma batches within kilometre-scale tension gashes generated by Permian dextral shearing, and should be considered as synkinematic sheeted intrusions. Finite strain analysis across the HuangshanKangguer shear zone provides rather high shear strain rates ( 4.5). Considering the location and alignment of the Ni-Cu-bearing mafic/ultramafic bodies along regional shear zones throughout Eastern Tianshan, it appears that wrench tectonics most likely controlled and focussed the intrusion of parent magmas. As a consequence, rifting related to post-orogenic extension is not required to account for Permian magmatic features of the Tianshan Belt. Finally, the Huangshan Ni-Cu bearing mafic/ultramafic intrusions are neither parts of an ophiolitic suture, nor of a dunite-cored Alaskan-type ore deposit, as postulated in some previous studies. In the light of these new results, we believe that structural controls and emplacement mechanisms of many $\mathrm{Ni}-\mathrm{Cu}$ sulphides deposits hosted by small intrusions (particularly funnel-shaped ones) should be (re-)evaluated from a structural and geophysical point of view.
\end{abstract}




\section{Keywords}

Synkinematic mafic/ultramafic complex, sheeted intrusion, Huangshan Ni-Cu deposits, Tianshan belt, Permian shear zones, strain restoration 


\section{Introduction}

Small mafic/ultramafic complexes and intrusions have been extensively studied because they host: i) world-class magmatic Ni-Cu \pm PGE sulphide deposits (e.g. Voisey's Bay, Jinchuan and Noril'sk deposits, Naldrett et al. 1997; Arndt et al. 2003; Chai and Naldrett 1992); ii) world-class Alaskan/Ural/Aldan-type PGE deposits (Himmelberg and Loney, 1995; Johan 2002, and review in Pettigrew and Hattori, 2006). The main characteristics of the $\mathrm{Ni}-\mathrm{Cu} \pm$ PGE sulphide ore deposits are (Naldret, 1999): i) mafic and ultramafic host rocks crystallized from mantle-derived magmas with high- $\mathrm{MgO}$ content; ii) there are many evidences of strong interactions between mafic-ultramafic magmas and sulphur-rich country rocks; iii) Intrusive complexes are small compared to giant layered mafic-ultramafic intrusions bearing PGE-Cr V-Ti deposits (e.g. the Bushveld complex); iv) ore bodies are almost located at the base of the intrusive complex and particularly within or close to magma conduits which can be funnel shaped as in Jinchuan (Chai and Naldrett, 1992); v) generally, magmatic Ni-Cu \pm PGE sulphide deposits are located in the vicinity of a major crustal fault or suture which enhanced vertical magma flow through the continental lithosphere; vi) these deposits are related to intracontinental rifting or continental break-up, probably associated with mantle plume (Groves and Bierlein, 2007). Although, similarities exist (alkaline-ultramafic magmas, small intrusion, fault control...), the key points mentioned above, clearly diverge from the definition of the Alaskan/Ural/Aldan type platinoid deposits (Pettigrew and Hattori, 2006). Indeed, in those late deposits, the PGE content is the main economic interest, intrusion are typically zoned ultramafic complexes with a mineralized dunite-core; the orthopyroxene is absent and platinoid minerals are rather associated with chromite within dunite than with $\mathrm{Ni}-\mathrm{Cu}$ sulphides. However, for both magmatic Ni-Cu sulphide and Alaskan/Ural/Aldan-type platinoid deposits, the emplacement mechanism is still matter to debate regarding the high 
density of the involved magmas derived from mantle. Two end-members mechanisms can be distinguished: i) molten rocks flow upward into a plumbing system that presents a complex 3D geometry potentially controlled by tectonic structures (active or inherited); ii) already crystallized ultramafic rocks ("solid intrusion") rise through the continental crust at the apex of a translithospheric diapir (Burg et al. 2009). However, in the case of molten rocks flowing into a plumbing system from the mantle, there are only a few studies (e.g. the Aguablanca Ni(Cu) sulphide deposit, Romeo et al. 2008) that illustrate how contemporaneous crustal deformation controls the geometry of magma conduits and how magma flows into it. 
This study presents the detailed architecture and the multiscale structural controls of the Ni$\mathrm{Cu}$ sulphide-bearing mafic-ultramafic intrusions of the Huangshan mining district in eastern Chinese Tianshan. As other magmatic Ni-Cu sulphide deposits of the Central Asian Orogenic Belt (CAOB) (see review of Mao et al. 2008), the Huangshan deposits, discovered in the 1970s, have been extensively studied and geochemistry, petrography and radiometric age data are now available in the international literature (Gu et al. 1995; Zhou et al. 2004; Zhang et al. 2008; Zhang et al. 2011). However, structural data remain unpublished, which brings integration difficult in the Tianshan geodynamic evolution. The mining works and the exceptional quality of exposures, allow us, through petrostructural, strain analysis and restoration, to propose that these small mafic-ultramafic intrusions emplaced during Permian wrench tectonics. Particularly, we claim that these intrusions hosting important $\mathrm{Ni}-\mathrm{Cu}$ ore bodies are spectacular examples of syntectonic magma chambers.

\section{Geodynamical and geological settings}

The CAOB contains many Ni-Cu-bearing sulphide deposits associated with small maficultramafic intrusions (Figure 1). Without exception, in Altay and in eastern Tianshan as well, all the deposits are located along or in the close vicinity of important crustal shear zones, which are part of a complex geodynamic evolution. The Tianshan mountains correspond to a Paleozoic accretionary-collisional orogen, reactivated and uplifted during Cenozoic deformation due to the ongoing convergence between India and Asia plates (Charvet et al. 2001; Laurent-Charvet et al. 2003; 2002; Molnar and Tapponnier 1975; Tapponnier and Molnar, 1979). From Ordovician to Late Carboniferous, the Tianshan belts formed through a southward-plunging sequence of subduction-collision welding the Junggar plate to the north and the Tarim plate to the south (Charvet et al. 2007). Along-strike, three suture zones separate four continental blocks and their associated volcanic arcs. These units are, from north 
to south (Figure 1): i) the Junggar block; ii) the North Tianshan belt; iii) the Central and South Tianshan domains; the South Tianshan domain being characterized by occurrences of ophiolitic mélange; iv) and a southern block ("Tarim block" on Figure 1) corresponding to the deformed northern edge of the Tarim plate. During these diachronous convergence stages, shortening across arcs and microplates was moderate and probably resulted in minor crustal thickening only. All these blocks were finally welded in the latest Carboniferous (Wang et al. 2007).

The Permian period is marked by important intracontinental wrenching that accommodates the eastward motion of Junggar and Yili blocks (Figure 1). The eastward displacement of these blocks, relative to Tarim Block, may be evaluated at $1160 \pm 380 \mathrm{~km}$ during the Permian (Wang et al. 2007). As a consequence, major right-lateral shear zones developed across the Tianshan belt; they are newly formed structures or reactivated Carboniferous suture zones (Laurent-Charvet et al. 2003; Wang et al. 2008). In the Tianshan, Permian magmatic rocks consist of widespread small-sized alkaline granites, mafic-ultramafic complexes and their bimodal volcanic equivalent including basalts and rhyolites (Pirajno et al. 2008). This volcanism appears in small continental red bed basins with numerous intercalated lava flows and volcanic breccia pipes, and in narrow deep-marine basins where Permian turbidites, olistotromes and alkaline pillow basalts are intruded by diabase and gabbro dykes (Shu et al. 2010). The petrogenesis of the Permian magmatism and the inferred geodynamic setting is still a matter of debate. A mantle contribution is generally advocated for the origin of Permian magmatism (Pirajno et al. 2008 and references therein). However, whilst most authors consider the Permian magmatism as the result of continental rifting, likely associated with mantle plumes (e.g. Pirajno et al. 2008; Xia et al. 2004; Zhou et al. 2004), recent studies argue for a model where post-collisional thinning of lithosphere and intraplate magmatism are controlled by transcurrent tectonics without plume contribution (Wang et al. 2009). For these 
authors, the coexistence of diverse magma sources, the syntectonic character of Permian plutons during transcurrent deformation (Wang et al. 2008) and the lack of major normal faults, argue for a continuous evolution from calc-alkaline to alkaline magmatism through Carboniferous convergence to Permian transcurrent tectonics. Moreover, Permian transcurrent tectonics plays an important role in the ore forming processes in Tianshan. Indeed, major dextral shear zones strongly controlled the distribution of gold and $\mathrm{Ni}-\mathrm{Cu}$ deposits along the trend of the belt. Most of these ore deposits are Permian in age (Zhang et al. 2008). This Permian mineralizing peak corresponds to high heat flow, magma emplacement and convective fluids channelized by major dextral shear zones. This thermal advective system may be responsible for regional-scale isotope resetting (De Jong et al. 2009). In eastern Tianshan, the mafic/ultramafic intrusions that bear the $\mathrm{Ni}-\mathrm{Cu}$ ore are mainly distributed within the Northern Tianshan (NTS), along the Huangshan-Kangguer shear zone (Figure 2). The NTS is composed of Carboniferous arc-related volcano-sedimentary and plutonic rocks crosscut by younger Permian intrusions. Carboniferous intrusions are generally highly deformed whereas Permian intrusions show syn-or post-tectonic features relative to dextral wrenching (Wang et al. 2008). It is noteworthy that a Permian volcano sedimentary basin is reported to the south of Yamansu iron mine (Figure 2). In eastern Tianshan the Ni-Cu bearing mafic/ultramafic bodies are either small intrusions (i.e. from 5 to $0.2 \mathrm{~km}$ ) or dyke swarms (see review in Mao et al., 2008). A large number of mafic/ultramafic intrusions and Ni-Cu sulphide ores, have been dated using various methods (i.e. SHRIMP U-Pb dating on magmatic zircon and Re-Os dating on ores) (Zhang et al. 2008; Zhou et al. 2004; Mao et al. 2008 and references therein). They range from $298 \mathrm{Ma}$ to $270 \mathrm{Ma}$, and define an Early Permian $\mathrm{Ni}-\mathrm{Cu}$ ore-forming peak in eastern Tianshan. Finally, it has been recently demonstrated, that Permian tholeiitic basalts found along the rim and within the Tu-Ha basin (Figure 2), are coeval and genetically linked with the Huangshanxi Ni-Cu bearing 
mafic/ultramafic intrusion (Zhou et al., 2006; Zhang et al., 2011).

\section{The Huangshan mafic/ultramafic intrusions}

The Huangshan Ni-Cu district (Figure 3) is composed of two main intrusions: the Huangshanxi intrusion to the west, dated at $269 \pm 2 \mathrm{Ma}$ (SHRIMP U-Pb age on zircon, Zhou et al. 2004), and the Huangshandong intrusion to the east. A small composite (i.e. granite and diorite) intrusive complex outcrops between the two main intrusions. These intrusions are aligned along an E-W trending major lineament which corresponds to the HuangshanKangguer shear zone (Figures 2 and 3). The intrusions are emplaced within the Lower Carboniferous Gandun formation, composed of volcano-sedimentary rocks, limestones, dark schists and meta-conglomerates. These rocks, which correspond to the development of a Lower Carboniferous arc, have been intruded by syn-arc Carboniferous intrusives strongly deformed and foliated at some place.

The Huangshanxi and the Huangshandong mafic/ultramafic intrusions present a cornue (i.e. comet) and a sigmoid (i.e. rhomb) map shapes respectively (Figures 4 and 5). Long axes orientation and asymmetry of those map shapes, suggest regional dextral strike-slip shearing along the Huangshan-Kangguer shear zone (Figure 3) (Brun and Pons, 1981). Mine wells, galleries and boreholes allowed $\mathrm{Li}$ et al. (1989) to draw a precise cross-section through the Huangshandong intrusions (Figure 5C). The intrusion presents a funnel shape centered above a potential feeder zone. This is compatible with the inward dipping of foliation of host rocks directly in contact with the intrusion (Figure 5B).

The two main intrusions developed a weak contact metamorphism. Generally, the contact aureole corresponds to dark metapelites (Figure 6A), less than $100 \mathrm{~m}$ width, with sparse biotites, white micas, and oxides growth. Within limestones, in contact with the Huangshanxi 
intrusion, contact metamorphism is responsible for the development of meter thick skarns with a garnet-diopside-zoisite-titanite-calcite assemblage (Figure 7B).

In order to precise chronological constraints between different magma batches and to account for potential role of the deformation, the relationships between the different magmatic facies have been studied here for both intrusions. The work of Li et al. (1989) has been compiled and completed by new data from surface cartography and mine galleries. The more informative mine gallery, studied in this work, is located on Figure 5B.

Both intrusions display an external foliated facies, made of strongly deformed gabbro and/or diorite (Figures 6A, B, C). This lithodemic rim is particularly well expressed at the Huangshanxi where it is nearly continuous around the intrusion (Figure 4A). The elongated part of the small composite intrusion, east of Huangshanxi, is also composed of foliated diorite. Deformation of this facies will be presented within the next section.

With exception of some localized structures, the internal magmatic facies are weakly deformed and comprised ultramafic and gabbroic magma batches showing typical magmatic mingling contacts (Figure 6D). In the galleries of Huangshandong mine, mingling and crosscutting relationships suggest that magma batches are younger toward the intrusion center. However, at some specific places, magmatic foliations indicate the contrary (see below).

\section{Structural analysis}

\subsection{Structures within the intrusions}

With exception of the external foliated diorite, the central part of the intrusions is weakly deformed and shows generally no widespread macroscopic preferred orientations. On the field, we did not recognized "the layered character of the majority of the rocks" described by 
Zhou et al. (2004) and we think that confusion must have been made. Indeed, intrusion massifs display regular sets of hydrothermal fractures and veinlets (Figure 6I), leading to a "dark" pervasive alteration within gabbros and ultramafic rocks, which may have been misinterpreted as magmatic layering. Yet, sparse but significant structures have been recognized from field and gallery outcrops (Figure 8).

\section{Solid-state deformation}

In gallery, E-W trending thrusts are observed (Figure 8). They are particularly well-expressed within ultramafic rocks, where compressive deformation is fluid-assisted yielding serpentinization and talcification of sigmoid deformed lenses. Both south and north vergencies have been observed. Dextral meter-thick E-W trending shear bands are well exposed in the southern part of the Huangshandong intrusion (Figures $6 \mathrm{H}$ and 7E, F). This solid-state deformation leads to grain size reduction which subsequently induced pervasive alteration of these shear bands (cf. "dark" areas in the gabbro). This alteration yields massive metasomatism characterized by carbonatization, chloritization and silicification of the deformed gabbro. Locally, this "propylitic" assemblage is completed with epidote, actinolite, iron oxides, tourmaline and muscovite crystallization.

Strictly similar propylitic alteration is observed in association with brittle-ductile normalsense shear zones (Figure 8). Steeply dipping normal-sense shears are regularly SE-trending. Gently dipping normal shears are underlined by the same "dark" propylitic alteration zones and associated set of sub-vertical extensional veins, mainly filled with calcite and quartz (Figure 8). Hybrid shear/dilatant veins filled with zoisite and quartz shear veins are observable. It is noteworthy that this zone of intense normal-sense shearing: i) is developed at the interface between two different magma batches, i.e. a gabbro to the NE and an amphibole 
peridotite to the SW (Figure 8); ii) has suffered a major hydrothermal alteration, and thus important fluid flows.

\section{Gently dipping magmatic foliation}

Just below those flat-lying normal-sense shear zones, the gabbro is intensively structured by a flat-lying foliation (Figure 8). The foliation is slightly crosscut by the normal-sense shear zones and associated tension gashes and is overprinted by the propylitic alteration. Northeastward, this foliation is less penetrative and finally disappears. The north-eastern contact of the gabbro with more external ultramafic rock slice is characterized by typical magma mingling breccias (similar to those in Figure 6D). When alteration is limited, thin sections, normal to the foliation, show alignments of idiomorphic plagioclases without any plastic deformation (Figure 7G). This planar fabric is therefore clearly diagnostic of a magmatic suspension flow. Unequivocal shear criteria have not been observed.

\subsection{Structures along the contact rim}

Observations along the northern contact of the Huangshanxi intrusion are very instructive (Figure 9). The external foliated diorite, which forms a nearly continuous rim around both principal intrusions (Figures 4 and 5), is characterized by a well developed vertical mylonitic foliation (Figure 6C), ENE to E trending shear planes (C planes; Figure 6E) and C' shear planes (Figures 6B and 7C). S vs. C planes measured obliquity angle show systematic dextral movements along these subvertical shear bands. Detailed mapping of the contact zone (Figure 9B) shows that shear bands and mylonitic fabrics are distributed, drawing an irregular anastomosing network affecting more internal ultramafic batches at some place (Figure 7D). Increments of solid state deformation are dominant and clearly evidenced by folded and 
sheared quartz and pegmatoids veins (Figures 6C and 9). Near the contact, schists and limestones are weakly deformed with exception of some folds with steeply-dipping axes. In these host rocks, pegmatoid veins from the intrusion are not sheared as it is the case within the foliated diorite (Figure 9A). It is noteworthy that, at some place, the map shape of the foliated diorite facies strongly suggests right lateral extensive jogs geometries in which the dioritic magma was injected, embedding decametric blocs of host rocks (Figure 9B). Precise mapping of the intrusion's western edge has revealed the existence of a triple junction, with a typical interference constrictive zone (Figure 9C). Moreover, at this place, the external foliated facies and the host schists are separated with a triangular or saddle reef decametric quartz vein (Figure 9C). This might be analogue to a large scale pressure shadow formed during regional strain when the intrusion was solidified.

The small composite intrusion between the Huangshandong and Huangshanxi comprises a dioritic band which is deformed for its main part (Figure 4). The diorite is affected here by a second order antithetic left-lateral shearing (Figure 4B). However, some part, preserved from shear bands and mylonitic foliation, presents two types of planar fabrics: the first type is a well-expressed layering, leading to alternation of dark ferromagnesian (mainly amphiboles) and light feldspathic layers (Figure 6F); the second type corresponds to diffuse metric pegmatoïd patches, in which amphiboles are aligned, defining a mineral foliation (Figure 6G). Both fabrics are devoid of intracrystalline strain.

\subsection{Structures within the host rocks}

The Lower Carboniferous Gandun formation is affected by the development of cleavage and shear planes. Xu et al. (2003) realized a detailed strain analysis of a large deformed zone within NTS including the Huangshan area. Stretched pebbles in metaconglomerates and caxes petrofabrics indicate a complex strain pattern, which is interpreted by these authors as 
relevant to a coaxial ductile compressional regime. However, this study did not account for pre-Permian deformation which corresponds to ductile Carboniferous Top-to-the North thrusting (D1) well identified in the Huangshan area (Charvet et al. 2007; Laurent-Charvet et al. 2005; 2001). Consequently, in some local areas partially preserved from Permian wrenching (D2), all strain markers are not coeval (see overprinting relationships on Figure $6 \mathrm{~J})$. Nevertheless, at the Huangshan area scale, with exception of those preserved areas (Figure 6J) and some macroscopic fold hinge zone (e.g. Figure 5), bedding and/or older foliation (S1) have been transposed to the syn-wrenching regional cleavage and shear plane orientations (S2 and mylonitic foliation on Figures 4 and 5). Stretching and mineral lineation are only poorly expressed on cleavage plane. On shear planes, a mylonitic lineation is underlined by elongated clasts of quartz and volcanic rocks (Figures 4 and 5).

The regional cleavage and shear planes are characterized by a chlorite-calcite-white micas assemblage, well developed within pressure shadows around clasts (Figure 7A). In greywackes, clasts of volcanic rocks, quartz and feldspar are flattened along the main cleavage plane. In limestones, cleavage is marked by recrystallized elongated carbonate grains with sparse twinning. These data indicates that metamorphic conditions prevailing during regional cleavage and shear plane development are relevant to the greenschist facies.

In the Huangshan area, regional shear plane and cleavage present dips varying from $60^{\circ}$ to the north to subvertical along the main Huangshan-Kangguer shear zone (Figures 4 and 5). Most of the measured mylonitic lineations are horizontal. Either at local or regional-scale, available satellite images clearly display two groups of lineaments: one trending ENE-WSW, parallel to the cleavage and the other trending E-W, parallel to the shear planes measured on the field (Figures 3 to 5). When considering that structures are almost subvertical in the study area, the systematic obliquity between shear planes and cleavage highly suggests right-lateral wrenching. In addition, all kinematic indicators (i.e. asymmetric pressure shadows, $\sigma$-type 
porphyroclasts, shear bands, elliptical map-shapes of intrusions...) indicate consistent dextral simple shear within the area (e.g. Figures 6B and 7A). Associated with this bulk dextral simple shear, a number of synthetic and antithetic second order fault and shear zones have been identified and mapped on the figures 4 and 5. In particular, as mentioned above, a leftlateral ductile shear zone is located inbetween the Huangshanxi intrusion and the smaller intrusive complex lying to the East (Figure 4).

For the same reason relevant to pre-Permian deformation (see above), 3D strain patterns are difficult to interpret from finite strain statistical analysis on deformed pebbles. Despite this statement, Xu et al. (2003) measured a mean Flinn K value around 1.8 in the Huangshan area. Still, at outcrop scale, close to high strain shear planes between the two main intrusions, aspect ratios of the sections of deformed boulders are comparable within the $\lambda_{1} \lambda_{3}$ plane and in the $\lambda_{2} \lambda_{3}$ plane. Consequently, in first approximation, we infer a bulk plane strain regime for the Permian right-lateral wrenching in the Huangshan area.

Hence, intrusions' geometries, local foliation trajectories and multi-scale kinematic indicators clearly highlight a bulk inhomogeneous dextral simple shearing.

\section{Finite strain analysis and restoration}

Regional scale strain field of plane strain deformation regime can be nicely studied and modelled through cleavage trajectory map analysis. Following Gumiaux et al. (2003) geostatistics are used here to compute automatic best-fit cleavage trajectory map for the overall $\sim 65 \mathrm{~km}$ long study area (Figure 3 ). Field structural measurements are only available for the two zones surrounding the Huangshanxi and Huangshandong intrusions (see Figures 4 and 5) but, due to exceptionally good rock exposure conditions throughout the entire area, 
map traces of the geological structures can easily be drawn from remote sensing analysis (Figures 3A and 10A), as detailed below.

\subsection{Digitizing procedure of the structures}

The high quality of the available satellite images (10 meters spatial resolution; Google Earth, 2009) and their precise georeferencing allows digitizing individual line segments, parallel to the local structural trend shown in the image (Figures $3 \mathrm{~A}$ and 10A, B). Combined with our own field observations, map structural geometry analysis lead us individualizing trace of i) foliation planes, ii) shear planes, iii) stratification planes and associated iv) fold axial plane traces, as follows:

- Most of the structures drawn from the satellite image analysis correspond to foliation planes (S2) or to bedding or older foliation (S1) which have been transposed to these regional foliation plane orientations, as documented above (Figure 10B). In the two field study zones, the strike of the linear structures shown in the images is parallel to the measured foliation ones (Figures 4 and 5). Moreover, field structural observations show that the Huangshan area displays a pervasive ductile deformation which is compatible with the scattered distribution of the foliation traces digitized in the map (Figure 10A). Accordingly, 1898 segments of foliation (s1) type have been digitized,

- Local obliquity in between segments' trend as well as sigmoid structures (Figure 10A, B) allows recognizing map traces of "large-scale" shear planes (c planes). 242 segments of that type have been recognized,

- According to field observations, folded bedding is not everywhere transposed to the cleavage orientation and a significant angle with foliation planes can be observed in some places (Figure 5). Similar structures have been observed in the satellite images and the structural lines forming curved shapes have thus been interpreted as bedding 
plane traces during digitizing procedure (Figure 10C). 293 segments of that kind have been digitized throughout the entire study area,

- Fold axial plane traces can also be drawn in the satellite image map from the structural pattern kind as exposed above (Figure 10C). Only 33 segments of that type have been recognized. As the fold axial traces strike almost parallel to the foliation planes (Figure10C), these two segment types can be regarded as a single one, perpendicular to $\lambda 3$ and parallel to $\lambda 1$ principal directions. This type is simply condensed to as "foliation traces" in the following.

Digitalization from the satellite images has been done at a 1:5,000 to $1: 10,000$ scale which results in the recognition of $\sim 150 \mathrm{~m}$ long linear structures on average. Local strike of the structures has been computed from the 2476 digitized line segments and reported as data points in the map (see Figure 10A).

\subsection{Directional data statistical analysis}

Foliation planes (including fold axial traces), as recognized in the satellite images, form a 1931 points set in total (Figure 10A). Data are spatially well distributed across the overall study area; they are limited to the host rocks of the Permian intrusions as no preferred structural orientation have been recognized in the satellite images, within the ultramafic bodies (Figure 10A). Foliation planes azimuth displays a normal type distribution (Figure 10D) with an average angle value of ${\mathrm{N} 76^{\circ}}^{\circ}$ and a circular variance of 0.03 (see Wan and Sandilands, 1995).

Data points corresponding to digitized shear plane traces (242 data points) are spatially grouped and, principally, aligned along approximately east trending lines or bands (see blue 
segments on Figure 10A); in particular, one continuous band stands out in the central part of the zone with about $40 \mathrm{~km}$ long for less that $1 \mathrm{~km}$ thick. As shown on rose diagram (Figure $10 \mathrm{E}$ ), shear planes strike $\mathrm{N} 88^{\circ}$ on average and display a rather small span range, with a very low circular variance of 0.01 (Wan and Sandilands, 1995). This direction, parallel to the data points forming bands (compare Figures 10D and 10E), likely corresponds to the average shearing direction throughout the studied Huangshan area and has thus been used for further computations in this study. Besides, the maximum azimuth angle values of the foliation planes correspond to the ones of the shear planes (compare rose diagrams, Figures 10D and $10 \mathrm{E})$; this and the obliquity in between foliation and shear planes directions are well compatible with a bulk dextral shearing throughout the Huangshan belt.

Following Ramsay and Graham (1970), the amounts of simple shear $\gamma$ can be directly calculated from the $\theta$ obliquity angle in between foliation and shear direction as follows:

$$
\tan (2 \theta)=2 / \gamma
$$

Regardless of its potential spatial variations throughout the map, the average obliquity angle value in between foliation and the shear planes directions is of $12^{\circ}$. From this, the average $\gamma$ simple shear amount is c.a. 4.49 throughout the Huangshan shear belt.

\subsection{Model of foliation trajectories}

In contrast with the very stable striking direction of the shear planes, the figure $\mathrm{n}^{\circ} 10 \mathrm{~A}$ displays clear lateral variations of the foliation trend. These local direction changes induce spatial variations of the obliquity angle in between foliation and shear planes direction and, then, of the finite shear strain amount. In a way to analyse and to image those map spatial variations, interpolation of foliation directions has been performed in order to compute an automatic, continuous foliation trajectory map. The method used is based on geostatistics with 
kriging interpolation. This approach, initially developed by Matheron $(1955,1962)$ for scalar variables, can be adapted to the interpolation of directional data sets (Gumiaux et al. 2003) and in particular to the automatic computation of trajectory maps (Gumiaux et al. 2004).

Geostatistical analysis involves a two folds approach: variogram computation and analysis which gives the spatial interdependence between measured data values - and kriging interpolation in between data points. The sample omni-directional variogram displays a substantial "nugget effect" of about 100 square degrees (Figure 10F). This evidences a significant fluctuation of the foliation directions for short distances - less than the $250 \mathrm{~m}$ computational lag of the sample variogram - which can be considered as a relative noise with regard to the scale considered in this study. "Regional-scale" tendencies (i.e. for distances larger than $250 \mathrm{~m}$ ) and correlation in between data values are marked by the increasing value of the sample variogram for increasing map distances (Figure $10 \mathrm{~F}$ ). As given by the range value on the variogram, the maximum correlation distance of $\sim 10 \mathrm{~km}$ means that a regular regional-scale change of foliation direction does not hold for the study area of the Huangshan belt. A theoretical exponential model function is well supported by the sample variogram points and in particular for short distances, in the increasing part of the diagram (Figure 10F), which is critical for interpolation.

Based on the above variogram analysis, the kriging interpolation of the directions measured along the 1931 data segments (Figure 11A) results in a foliation trajectory map which highlights spatial trends of the $\lambda 1$ axis throughout the shear belt (Figure 11B; see Gumiaux et al. (2004) for details on trajectories construction). At first order, foliation trajectories strike almost parallel to the average $\mathrm{N}^{\circ} 6^{\circ}$ direction calculated from the overall data set. In more details, trajectories display wavy shapes throughout the map, and come closer to each others in certain zones or bands which forms map scale sigmoid type structures (Figure 11B). 


\subsection{Shear strain quantification}

In order to quantify observed lateral finite strain variations, $\gamma$ shear strain amount has been computed along a profile perpendicular to the average N88 shear direction (Figure 11D); here again, $\gamma$ is directly calculated from the obliquity angle in between the local interpolated foliation direction and the average regional shear direction. $\gamma$ ranges from 2 to a maximum of 7.7 along the $10 \mathrm{~km}$ long profile (Figure 11D). First order tendencies show a regular increase from north to south. Local maxima of the profile highlight three zones of higher shear strain, i.e. three second order shear bands of about $1 \mathrm{~km}$ width, one of these running along the southern edge of the Huangshandong intrusion (Figure 11D). The 4.6 average $\gamma$ value calculated from this profile is well consistent with the 4.49 one obtained from the statistical analysis of the entire data points set (cf. statistical analysis, above). The average shear strain value is of 3.5 across the Huangshandong body and regularly increases southward, toward the localised shear band (Figures 11B, D).

\section{Interpretation}

Most of these data and analysis provide valuable constraints to: i) regional strain field and intrusive shape restoration; ii) the relationships between intrusion emplacement and regional strain field; iii) the major dynamic processes involved in the intrusion construction.

\subsection{Intrusion shape restoration}

From the above strain analysis, the Huanshang-Kangguer shear zone displays a rather high $\sim 4.5$ average $\gamma$ involving about $50 \mathrm{~km}$ of relative displacement only due to pervasive ductile 
deformation. In addition, recognition of regional scale sigmoid structures highlights: i) large scale dextral simple shear, consistent with the local kinematical structural field observations, and ii) lateral spatial variations of the shearing throughout the belt, i.e. bulk inhomogeneous dextral strike-slip simple shearing. In particular, one sigmoid structure of the foliation is the same location as the Huangshandong massif (Figure 11C); coincidence of the intrusion geometry with the deformation pattern within the surrounding rock units highly suggests a common evolution during regional scale shearing

From this, considering a plane-strain deformation regime in the horizontal plane, one can restore initial geometry of the geological boundaries of the Huangshandong intrusion (Gumiaux et al. 2004). First, a pinning point is arbitrarily fixed along the northern edge of the Huangshandong massif (Figure 11B). Then, displacement relative to the corresponding "fixed" line is computed from the $\gamma$ value, along the AA' profile (Figure 11E). Displacement is positive eastward and calculation is performed each $200 \mathrm{~m}$ along the profile. Consistently with the $\gamma$ curve, the resulting relative displacement profile displays higher displacement gradients to the south of the shear belt than to the north (cf. slope change of the profile curve around 5-6 km distance, Figure 11E). Finally, deformation restoration is applied as an heterogeneous sinistral simple shearing parallel to the $\mathrm{N} 88^{\circ}$ direction (Figure 12).

In its present-day state, outline of the Huangshandong intrusion displays an asymmetric shape that marks out the dextral shearing of the belt (Figures 11C and12). When applying the overall relative displacement, as computed from the $\gamma$ value, the intrusion displays outline with an opposite rhomb shape (Figure 12A). This fully restored shape does not likely fit with an initial configuration. In addition, this would involve very high internal strain that is not observed (see above). In turn, assuming that the initial intrusion outline was much better symmetrical, with sub-perpendicular edges (i.e rectangular shape), only 45 to $50 \%$ of the total shearing restoration amount reflects the present-day outline of the Huangshandong intrusion 
(Figure 12B). It is noteworthy that the computed $\gamma$ profile, which crosses the Huangshandong massif, is well supported by the restoration of the intrusion's shape as even both tips of the outline are reasonably restored in the map (Figure 12B).

These restorations clearly show that the Huangshandong intrusion was emplaced during the course of the bulk regional scale shearing. This implies that active dextral shearing occurred during Early Permian in the Eastern Tianshan.

\subsection{Regional dextral strike-slip shearing and intrusion emplacement}

Where strain is observable, e.g. within the external foliated diorite, the intrusions are dominantly affected by solide-state deformations. However, several data constitutes clear evidences of magmatic and/or subsolidus deformation compatible with the regional strain field: i) the layering and the mineral foliation observed within the external foliated diorite (Figures 6F, G) are fabrics preserved from subsequent ductile strain. Particularly, this layering, being devoid of intracrystalline strain and parallel to the shear plane (a second order NE-trending sinsistral shear zone at this place), is interpreted as resulting from deformationassisted melt segregation at the solid-liquid transition (Barbey, 2009); ii) the extensive jog geometries observed along the intrusion contacts (Figure 9B), are also diagnostic of melt injection within dilatant site during bulk regional simple shear deformation; iii) With sparse limestones lenses, the external foliated diorites experienced the higher strain rate through the Huangshan area. Mylonites within this facies are nearly continuous, thus defining a sheared peripheral cortex for each intrusion. We interpret this peculiar strain localization as originating from a high viscosity contrast between host rocks and incipient diorite melt injection; such rheological configuration can lead to a weakly deformed zone within the host rocks along the contact (see Figure 9A), combined with preserved mineralogical layering at 
some place. Consequently, we infer that this external foliated diorite might represent the primarily-emplaced magma during the intrusion construction. In addition, the western edge of the Huangshanxi intrusion shows a small scale triple junction (Figure 9C) which argues for interference between regional simple shear and local strain field induced by pluton intrusion (Brun and Pons, 1981). However, the reduce scale of this constrictional zone, associated with the very small extend of the thermal aureoles, suggests that these intrusions are not expanding plutons. They likely correspond to intermediate small-sized magma chambers, regularly discharge towards the surface through an efficious plumbing system (see discussion below). Solid-state ductile and brittle strain largely overprints these evidences of molten-state deformation. High temperature C/S fabrics, as defined by Berthé et al. (1979), have not been observed along the dioritic margin of the intrusions. They likely were overprinted by lower temperature shear bands, mylonitic foliation and C' planes (Figures 6B, E and 7C). Particularly, these structures are all associated with a propylitic alteration mainly characterized by massive carbonatization and chloritization. This assemblage, in equilibrium with greenschist facies conditions, is encountered along the large-scale regional shear zone (Figure 7A) as well as around and within the intrusions (Figures 6H and 7C, E, F). Because structure trends and kinematics are similar within gabbroic and ultramafic rocks, we think that the main serpentinization event ( \pm actinolite and talc) of ultramafics (eg. Figure 7D) is coeval and analogue of this deformation-enhanced propylitic alteration within gabbros. The origin and the scale of these aquo-carbonic fluid flows is not yet established (see discussion below), however growth of tourmaline (Figure 7E) and the high water content of parent magmas (Zhou et al. 2004) argue for a potential deuteric origin of this deformation-enhanced hydrothermal alteration.

At the intrusion scale, the triangular large quartz vein observed at Huangshanxi (Figure 9C) likely corresponds to a strain shadow, indicating, as folded quartz veins in the external 
foliated diorite (Figure 6C), that strike-slip deformation continued well after intrusion solidified. Furthermore, the strain restoration presented above (Figure 12) attests that if intrusions solidified before regional wrenching (i.e. pre-tectonic intrusion in the sense of Paterson and Tobisch, 1988), intrusions should have experienced strong internal strain, which is not the case. Corollary, a solid-state strain localization restricted to the external foliated diorite is unable to achieve such finite strain and shapes alone.

Therefore, all these points attest that strains have accumulated during and after magma crystallization in a bulk dextral wrenching. Thus, the Huangshan intrusions are not pretectonic intrusions but are at least in part synchronous with Early Permian regional strike-slip deformation.

\subsection{Intrusion construction dynamics (Figure 13)}

The lack of widespread igneous layering suggests that magma chamber processes, as hydrodynamic sorting and gravity-driven melt/crystals separation, are not dominant during the intrusions construction (see review on layering in Barbey, 2009). This assumption does not discard: i) local gravity-driven separation between sulphide drops and silicate melts, explaining the stratoid but non massive ore bodies; ii) cumulative and poikilitic textures observed within ultramafics particularly.

Moreover, geometry of magma "slices" and magmatic mingling are diagnostic of the important role of injection processes which might be responsible for the intrusion-scale layering (Barbey, 2009). In galleries, we identified a gently dipping magmatic foliation located at the top of a gabbroic magma batch (Figures 8 and 7G). This fabric, not directly compatible with the regional dextral shearing, is interpreted to be the result of magmatic injection process involving viscosity contrasts between different magma pulses (Nicolas 1992 and references herein). An interpretation of the emplacement dynamics is proposed on the 
figure $n^{\circ} 13$. During the injection of the gabbroic magma batch observed on the figure $n^{\circ} 8: i$ ) viscosity contrast between injected magma and its ultramafic roof batch (fully crystallized?) was high, resulting in a magmatic foliation development; ii) viscosity contrast between injected magma and its ultramafic hanging-wall batch was low enough, leading to magmatic mingling.

Furthermore, these flat-lying interfaces between mafic and ultramafic batches are used/reused in normal-sense shear during on-going solid-state deformation (Figure 8). SE-trending and steeply-dipping normal faults are also spatially associated with this low angle normalsense shear zone. It is noteworthy that the direction of the normal faults is broadly compatible with the regional dextral strike-slip shearing. This localized normal-sense shearing is also the locus of intense fluid flow leading to intense and late hydrothermal "propylitic" alteration (Figure 8). Based on these observations, we interpret the normal-sense shear zones as potential feeder zones of the intrusion (Figure 13). In our interpretation, the feeder zones correspond to SE-trending extensional fractures formed during the dextral strike-slip tectonic event. Such feeder zones in strike-slip regime, have been recognized in many plutons (e.g. Vigneresse, 1995) and intrusions, as for example the mafic/ultramafic Ni-Cu-bearing Aguablanca complex in Spain (Romeo et al. 2008). These tension gashes have been injected with rising magmas during intrusion construction, and have channelized deuteric and/or metamorphic fluids during subsequent solid-state deformation.

Fluid flows also occurred along compressive structures, as evidenced by serpentinized thrusts which accommodated part of the shortening within the intrusion (Figures 8 and 13). It is noteworthy that the normal-sense water content of parental magmas (i.e. 3 wt.\%, Zhou et al. 2004) favours contribution of deuteric fluids in observed hydrothermal alteration and serpentinization. 
To summarize, our works demonstrate that the Huangshan intrusions correspond to syntectonic sheeted mafic/ultramafic intrusions, rather than layered intrusions as suggested by previous studies (e.g. Zhou et al. 2004).

\section{Discussion}

These characteristic have not been previously recognized in the other mafic/ultramafic Permian intrusions along the Tianshan belt. However, it is not discarded that the few intrusions far from main Tianshan shear zones (cf. Figure 2) show no clear evidence of syntectonic emplacement. Particularly, in the Huangshan area; we think that the presence of limestones within host rocks (Figure 3), greatly favored the regional strain localization in the upper crust, thus enhancing emplacement of small intermediate magma chambers. Inversely, intrusions emplaced within limestones induced perturbation within the regional deformation pattern: for example spectacular folds in the western side of the Huangshandong intrusion (Figure 5) may be interpreted as resulting from strain localization within the limestones and the external foliated diorite. Similar results have been obtained from experimental works dealing with rigid particles embedded within a sheared viscous matrix (Arbaret et al. 2001).

In most cases, the proximity with main shear zones suggest that most of the $\mathrm{Ni}-\mathrm{Cu}$-bearing intrusions obey the same emplacement model than Huangshan ones. At least in the Tianshan oriental, during the Early Permian wrenching, those major shear zones acted as dominant conducts for mafic melts derived from mantle melting (Figure 14). As exposed above, the mantle melting process is still mater to debate in the Tianshan at Permian times. Based on identification of thick basaltic Permian series under the Tarim sedimentary cover and A-type granites widespread through the Tianshan belt, the occurrence of an Early Permian Large igneous province associated with astenospheric mantle plume during post-orogenic extension has been proposed (Zhou et al. 2004; Zhang et al. 2010; Pirajno et al. 2008). The scale and 
origin of the plume is beyond the scope of this study, nevertheless we suggest that thermal astenospheric bulging and lithospheric thinning are much more localized and restricted along lithospheric shear zones than proposed in models involving belt-scale post-orogenic extension. Such localization of crust thinning and thermal anomaly along trans-lithospheric shear zones are now well-established in orogeny as the Pyrenean belt (Lagabrielle and Bodinier, 2008).

As mentioned in introduction, the Permian shear zones are also recognized as high heat flux zones, where hot convective fluids are responsible for numerous mesothermal gold mineralizations and a regional-scale isotope resetting observed westward by De Jong et al. (2009). In the Huangshan area, carbonatization by $\mathrm{CO}_{2}$-rich fluids (e.g. Figure 7A) is massive and extensive within and around the intrusions. Nevertheless, no istopic and fluid inclusion studies are available to decipher the origin, nature and temperature of those $\mathrm{CO}_{2}$-rich fluids. We think that the decarbonatation of limestones induced by magma emplacement (skarn formation, Figure 7B), is not of sufficiently extent to explain this observed carbonatization. Then, we favor a CO2 mantellic source (Figure 14), "leaking” along lithospheric shear zones and compatible with the origin of intrusion parental magmas (Zhou et al. 2004; Zhang et al. 2011). At the surface such shear zones might be associated with deep marine pull-apart basins, filled with pillow basalts, olistrotromes and turbidites (Figure 14), and similarly to those described at Baiyanggou by Shu et al. (2010). In accord with Zhang et al. (2011), we interpret the mafic/ultramafic intrusions of Huangshan as magma conduits feeding these basins with volcanic effusives.

\section{Concluding points}

From this study two levels of conclusion can be withdrawn:

At the regional scale: 
1. The Huangshan Ni-Cu-bearing mafic/ultramafic complexes are not layered intrusions; instead, they are sheeted intrusions emplaced by injection of successive mafic/ultramafic magma batches.

2. Tension gashes, compatible with regional shearing, form the plumbing system (i.e. feeding zones) of magmas uprising from partial melting zone within the mantle.

3. The Huangshan intrusions emplaced during the course of Permian regional scale dextral inhomogeneous simple shearing and must be considered as synkinematic sheeted intrusions.

4. Finite strain analysis across the Huangshan-Kangguer shear zone gives rather high shear strain amount ( 4.5) with second order shear bands.

5. According to the alignment of the $\mathrm{Ni}-\mathrm{Cu}$-bearing mafic/ultramafic intrusives along regional shear zones throughout eastern Tianshan, such high shear strains appear to control and focus parent magmas through such plumbing systems.

6. Our emplacement model implies "classical" opening of large scale tension gashes acting as feeder zones for intrusion during wrenching. Consequently, a rifting event during post-orogenic extension, commonly evoked by authors, is not required during Permian to explain such magmatic features of the Tianshan belt.

7. Finally, the Huangshan Ni-Cu-bearing mafic/ultramafic intrusions are neither parts of ophiolitic suture zone, nor dunite-cored Alaskan-type ore deposits as mentioned in previous studies.

For general purposes:

1. While synkinematic emplacement process along crustal and lithospheric shear zones is commonly invoked for granitoïds, this study shows one of the unique cases for such mechanism addressing mafic/ultramafic intrusions. 
1. In light of the results, we think that the structural controls and emplacement mechanisms of many $\mathrm{Ni}-\mathrm{Cu}$ sulphides deposits hosted within small intrusions (particularly those presenting a funnel-shaped profile) have to be (re-)evaluated from geological and geophysical data.

2. Strain restoration is a powerful approach to evaluate the synkinematic character of magma intrusive bodies.

\section{Acknowledgements}

We wish to thank Jacques Charvet and Liangshu Shu for fruitful discussion on Tianshan geodynamics and metallogeny. Nicole Le Breton is also thanked for her expertise on mineralogy and petrography. Sylvain Janiec from ISTO has realized very high quality polished thin sections from the Huangshan district. We would like to express our gratitude to the Tianlong minerals company which greatly facilitated our work on field as well as in the Huangshan mine galleries. The drivers Xu Tao and Qi Yuming are friendly thanked. Authors are also grateful to B. Natalin for his constructive comments. This study is supported by the international convention between the Universities of Orléans and Nanjing. 


\section{References}

Arbaret, L., Mancktelow, N. S., Burg, J.-P., 2001. Effect of shape and orientation on rigid particle rotation and matrix deformation in simple shear flow. Journal of Structural Geology 23(1), 113-125.

Arndt, N. T., Czamanske, G. K., Walker, R. J., Chauvel, C., Fedorenko, V. A., 2003. Geochemistry and Origin of the Intrusive Hosts of the Noril'sk-TalnakhCu-Ni-PGE Sulfide Deposits. Economic Geology 98, 495-515.

Berthé D., Choukroune P., Jégouzo P., 1979. Orthogneiss, mylonite and non coaxial deformation of granites: the example of the South Armorican Shear Zone. Journal of Structural Geology 1, 31-42.

Barbey, P., 2009. Layering and schlieren in granitoïds: a record of interactions between magma emplacement, crystallization and deformation in growing plutons. GEOLOGICA BELGICA (2009) 12/3-4, 109-133.

Brun, J. P.and Pons, J., 1981. Strain patterns of pluton emplacement in a crust undergoing non-coaxial deformation, Sierra Morena, Southern Spain. Journal of Structural Geology 3(3), 219-229.

Burg, J.-P., Bodinier, J.-L., Gerya, T., Bedini, R.-M., Boudier, F., Dautria, J.-M., Prikhodko, V., Efimov, A., Pupier, E., Balanec, J.-L.,2009. Translithospheric Mantle Diapirism: Geological Evidence and Numerical Modelling of the Kondyor Zoned Ultramafic Complex (Russian Far-East). Journal of Petrology 50, 289-321.

Chai, G. and Naldrett, A. J., 1992. The Jinchuan Ultramafic Intrusion: Cumulate of a HighMg Basaltic Magma. Journal of Petrology 33, 277-303. 
Charvet J., Laurent-Charvet S., Shu L.S., Ma R. S., 2001. Paleozoic Continental Accretions in Central Asia Around Junggar Block: New Structural and Geochronological Data. Gondwana Res., 4(4), 590-592.

Charvet, J., Shu, L.S., Laurent-Charvet, S., 2007. Palaeozoic structural and geodynamic evolution of eastern Tianshan (NW China): welding of the Tarim and Junggar plates. Episodes 30(3), 162-186.

De Jong, K., Wang, B., Faure, M., Shu, L. S., Cluzel, D., Charvet, J., Ruffet, G., Chen, Y., 2009. New 40Ar/39Ar age constraints on the Late Palaeozoic tectonic evolution of the western Tianshan (Xinjiang, northwestern China), with emphasis on Permian fluid ingress. Int. J. Earth Sci. 98, 1239-1258.

Google Earth, "Huangshan area." Low.left: N42¹2’20” - E94²3'10" / upp.right: N42¹9’20” - E9458'15”. - Nasa; 2004 - December 2009.

Groves, D. I. and Bierlein, F. P., 2007. Geodynamic settings of mineral deposit systems. Journal of the Geological Society 164(1), 19-30.

Gu, L.-X., Zhu, J.-L., Guo, J.-C., Liao, J.-J., Yan, Z.-F., Yang, H., 1995. Geology and genesis of the mafic-ultramafic complexes in the Huangshan-Jing'erquan (HJ) belt, East Xinjiang. Chinese Journal of Geochemistry 14, 97-116.

Gumiaux, C., Gapais, D., Brun, J.P., 2003. Geostatistics applied to best-fit interpolation of orientation data. Tectonophysics, 376(3-4), 241-259.

Gumiaux, C., Brun, J.P., Gapais, D., 2004. Strain removal within the Hercynian shear belt of central Brittany (western France): Methodology and tectonic implications. In: Alsop, G.I. et al., eds. Flow processes in faults and shear zones, Geological Society [London] Special Publication. 
Himmelberg, G. R. and Loney, A. L., 1995. Characteristics and petrogenesis of Alaskan-Type Ultramafic-Mafic Intrusions, Southeastern Alaska. U. S. Geological Survey Professional Paper 1564, 47pp.

Johan, Z., 2002. Alaskan-type complexes and their platinum-group element mineralization. In: Cabri, L.J. (Ed.), Geology, Geochemistry, Mineralogy and Mineral Beneficiation of Platinum-group Elements, vol. 54. Can. Inst. Min. Metall. Sp., 669-719.

Lagabrielle, Y. and Bodinier, J.L., 2008. Submarine reworking of exhumed subcontinental mantle rocks : field evidence from the Lherz peridotites, French Pyrenees. Terra Nova 20 (1), 11-21.

Laurent-Charvet, S., 2001. Accrétions continentales en Asie centro-orientale : évolution géodynamique et structurale du Tianshan et du Junggar oriental (nord-ouest Chine) au Paléozoïque, Ph.D thesis, University of Orléans, Orléans, France, 312 pp.

Laurent-Charvet S., Charvet J., Shu L. S., Ma R. S., Lu H. F., 2002. Palaeozoic late collisional strike-slip deformations in Tianshan and Altay, Eastern Xinjiang, NW China. Terra Nova 14, 249-256.

Laurent-Charvet S., Charvet J., Monié P., Chen Y., Shu L. S., 2003. Late Paleozoic strike-slip shear zones in eastern central Asia (NW China) : New structural and geochronological data. Tectonics, 1099-1101.

Laurent-Charvet, S., Charvet, J., Shu, L.S., 2005. Middle and Late Palaezoic northward deformations in Tianshan (NW China): new structural insights along field cross-sections in South, Central and North Tianshan units, IGCP 480 meeting, Irkutsk, 25-27 July 2005, abstract volume, pp. 234-239.

Li, D.H., Bao, X., Zhang, B., Han, Z., Lan, G., Zheng, Z., et al., 1989. Investigation of geology, geophysics and geochemistry of the Huangshan $\mathrm{Cu}-\mathrm{Ni}$ metallogenic belt for mineral exploration. Unpublished report by National 305 project office in Xinjiang, 418 pp. In Chinese.

Mao, J. W., Pirajno, F., Zhang, Z. H., Chai, F. M., Wu, H., Chen, S. P., Cheng, L. S., Yang, J. M., Zhang, C. Q., 2008. A review of the Cu-Ni sulphide deposits in the Chinese Tianshan and Altay orogens (Xinjiang Autonomous Region, NW China): Principal characteristics 
and ore-forming processes. Journal of Asian Earth Sciences, Geodynamics and Metallogeny of the Altaid Orogen 32(2-4), 184-203.

Matheron, G., 1955. Application des méthodes statistiques à l'évaluation des gisements. Annales des mines, 144, 50-75.

Matheron, G., 1962. Traité de géophysique appliquée, Technip, Paris.

Molnar, P. and Tapponnier, P., 1975. Cenozoic tectonics of Asia: Effects of a continental collision. Science 199, 419-426.

Naldrett, A. J., Keats, H., Sparkes, K., Moore, R., MacKenzie, C., 1997. The Voisey's Bay Ni-Cu-Co deposit, Labrador, Canada: implications for exploration. International Exploration, Institution of Mining and Metallurgy.

Naldrett, A. J., 1999. World-class Ni-Cu-PGE deposits: key factors in their genesis. Mineralium Deposita 34, 227-240.

Paterson, S.R. and Tobisch, O.T., 1988. Using pluton ages to date regional deformations: problems with commonly used criteria. Geology 16, 1108-1111.

Nicolas, A., 1992. Kinematics in Magmatic Rocks with Special Reference to Gabbros. Journal of Petrology 33, 4, 891-915.

Pettigrew, N. T. and Hattori, K. H., 2006. The Quetico Intrusions of Western Superior Province: Neo-Archean examples of Alaskan/Ural-type mafic-ultramafic intrusions. Precambrian Research 149(1-2), 21-42.

Pirajno, F., Mao, J., Zhang, Z., Zhang, Z., Chai, F., 2008. The association of mafic-ultramafic intrusions and A-type magmatism in the Tian Shan and Altay orogens, NW China: Implications for geodynamic evolution and potential for the discovery of new ore deposits. Journal of Asian Earth Sciences, Geodynamics and Metallogeny of the Altaid Orogen 32(2-4), 165-183. 
Ramsay, J.G., Graham, R.H., 1970. Strain variations in shear belts. Canadian journal of Earth Sciences, 7, 786-813.

Romero, I., Tejero, R., Capote, R., Lunar, R., 2008. 3D gravity modeling of the Aguablanca stock, tectonic control and emplacement of a Variscan gabbronorite bearing a Ni-Cu_PGE ore, SW Iberia. Geol. Mag. 145 (3), 345-359.

Shu, L., Wang, B., Zhu, W., Guo, Z., Charvet, J., Zhang, Y., 2010. Timing of initiation of extension in the Tianshan, based on structural, geochemical and geochronological analyses of bimodal volcanism and olistostrome in the Bogda Shan (NW China). International Journal of Earth Sciences, 1-17.

Tapponnier, P. and Molnar, P., 1979. Active faulting and Cenozoic tectonics of the Tienshan, Mongolia and Baykal regions. J. Geophys. Res. 84, 3425-3459.

Vigneresse, J-L., 1995. Control of granite emplacement by regional deformation. Tectonophysics 249, 173-186.

Wan, A.R.H., Sandilands, M., 1995. Introduction to geological data analysis. Blackwell Sciences, $446 \mathrm{p}$.

Wang, B., Chen, Y., Zhan, S., Shu, L., Faure, M., Cluzel, D., Charvet, J., Laurent-Charvet, S., 2007. Primary Carboniferous and Permian paleomagnetic results from the Yili Block (NW China) and their implications on the geodynamic evolution of Chinese Tianshan Belt. Earth and Planetary Science Letters 263(3-4), 288-308.

Wang, Y., Li, J., Sun, G, 2008. Postcollisional Eastward Extrusion and Tectonic Exhumation along the Eastern Tianshan Orogen, Central Asia: Constraints from Dextral Strike-Slip Motion and 40Ar=39Ar Geochronological Evidence. The Journal of Geology, 2008, volume 116, 599-618.

Wang, B., Cluzel, D., Shu, L. S., Faure, M., Charvet, J., Chen, Y., Meffre, S., De Jong, K., 2009. Evolution of calc-alkaline to alkaline magmatism through Carboniferous 
convergence to Permian transcurrent tectonics, western Chinese Tianshan. Int. J. Earth Sci. $98,1275-1298$.

Xia, L.-Q., Xu, X.-Y., Xia, Z.-C., Li, X.-M., Ma, Z.-P., Wang, L.-S., 2004. Petrogenesis of Carboniferous rift-related volcanic rocks in the Tianshan, northwestern China. Geological Society of America Bulletin 116, 419-433.

X.B.G.M.R. (Xinjiang Bureau of Geology and Mineral Resources),1992. Geological map of Xinjiang Uygur Autonomous Region, scale 1:2,000,000. Geological Publishing House, Beijing.

Xu X.-W, Ma T.-L, Sun L.-Q, Cai X.-P, 2003. Characteristics and dynamic origin of the largescale ductile compressed zone formed in a Carboniferous back-arc basin, Jiaoluotage, Eastern Tianshan Mts., China. J. Struct. Geol., 25, 1901-1915.

Zhang, C.-L., Li, Z.-X., Li, X.-H., Xu, Y.-G., Zhou, G., Ye, H.-M., 2010. A Permian large igneous province in Tarim and Central Asian orogenic belt, NW China: Results of a ca. 275 Ma mantle plume? Geological Society of America Bulletin 122, 2020-2040.

Zhang, L., Qin, K., Xiao, W., 2008. Multiple mineralization events in the eastern Tianshan district, NW China: Isotopic geochronology and geological significance. Journal of Asian Earth Sciences, Geodynamics and Metallogeny of the Altaid Orogen 32(2-4), 236-246.

Zhang, M., Li, C., Fu, P., Hu, P., Ripley, E. M., 2011. The Permian Huangshanxi Cu-Ni deposit in western China : intrusive-extrusive association, ore genesis, and exploration implications. Mineralium Deposita 46, 153-170.

Zhou, D. W., Liu, Y. Q., Xin, X. J, Hao, J. R., Dong, Y. P., Ouyang, Z. J., 2006. Formation of the Permian basalts and implications of geochemical tracing for paleo-tectonic setting and regional tectonic background in the Turpan-Hami and Santanghu basins, Xinjiang. Sciences China D 49, 584-596 (in Chinese).

Zhou, M.-F., Michael Lesher, C., Yang, Z., Li, J., Sun, M., 2004. Geochemistry and petrogenesis of $270 \mathrm{Ma} \mathrm{Ni-Cu-(PGE)} \mathrm{sulfide-bearing} \mathrm{mafic} \mathrm{intrusions} \mathrm{in} \mathrm{the} \mathrm{Huangshan}$ 
district, Eastern Xinjiang, Northwest China: implications for the tectonic evolution of the Central Asian orogenic belt. Chemical Geology 209(3-4), 233-257. 


\section{Figure captions}
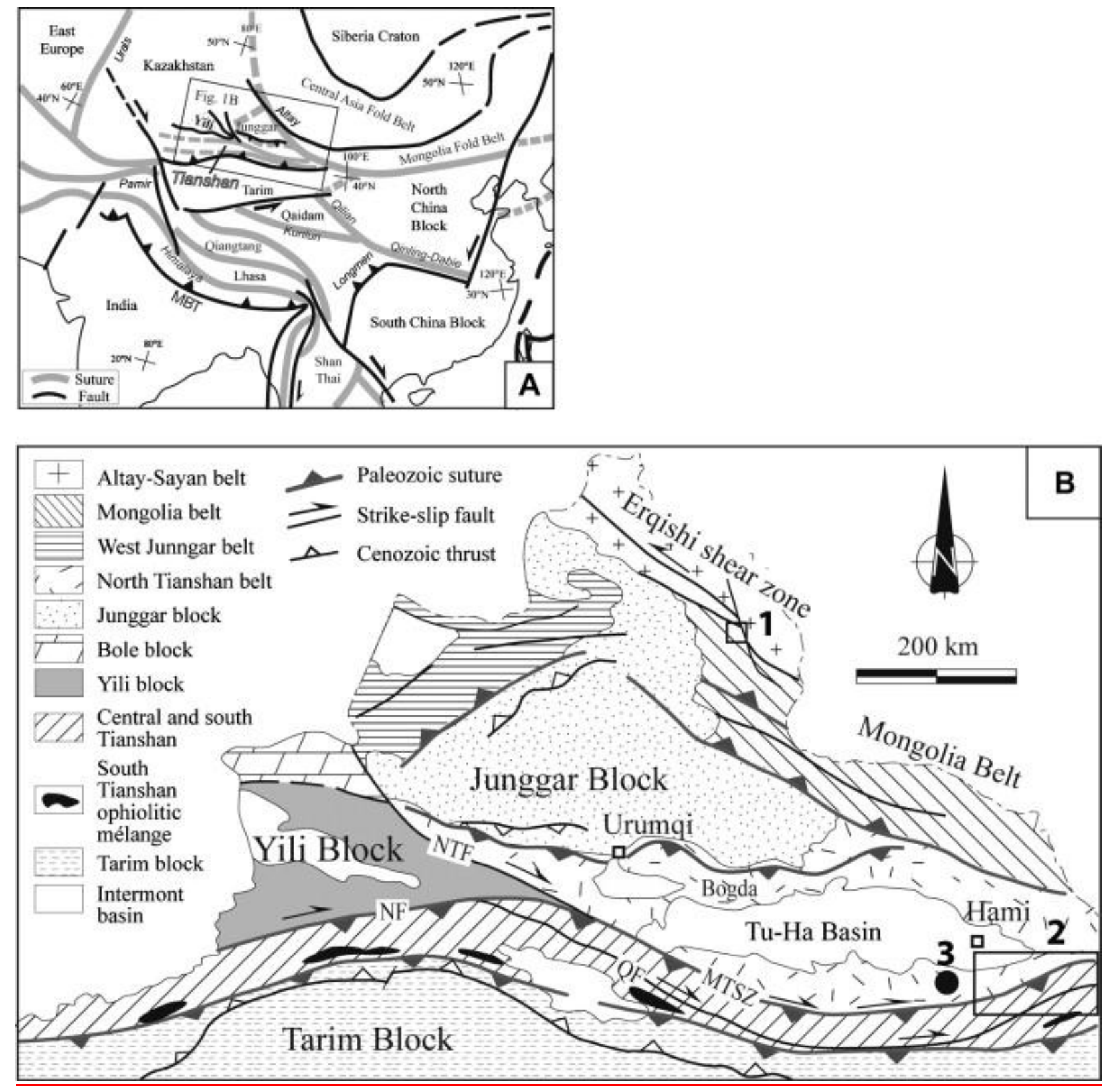

Figure 1: A) tectonic sketch map of Central Asia showing major suture, blocks and the structural position of the Tianshan belt (from Wang et al. 2007); B) Structural map of the Chinese Tianshan belt (modified from Wang et al. 2007). Strike-slip faults accommodate the Permian dextral wrenching along the belt. NTF: North Tianshan fault, NF: Nalati Fault, MTSZ: Main Tianshan Shear Zone, QF: Qingbulake Fault. Distribution of the main magmatic $\mathrm{Cu}-\mathrm{Ni}$ sulphide ore districts in Tianshan: 1 . Kalatongke district; 2. Eastern Tianshan ore belt 
(inset corresponds to the Figure 2); 3. Hongling deposit. The Pobei ore district in the Tarim block is out of the southern map border.

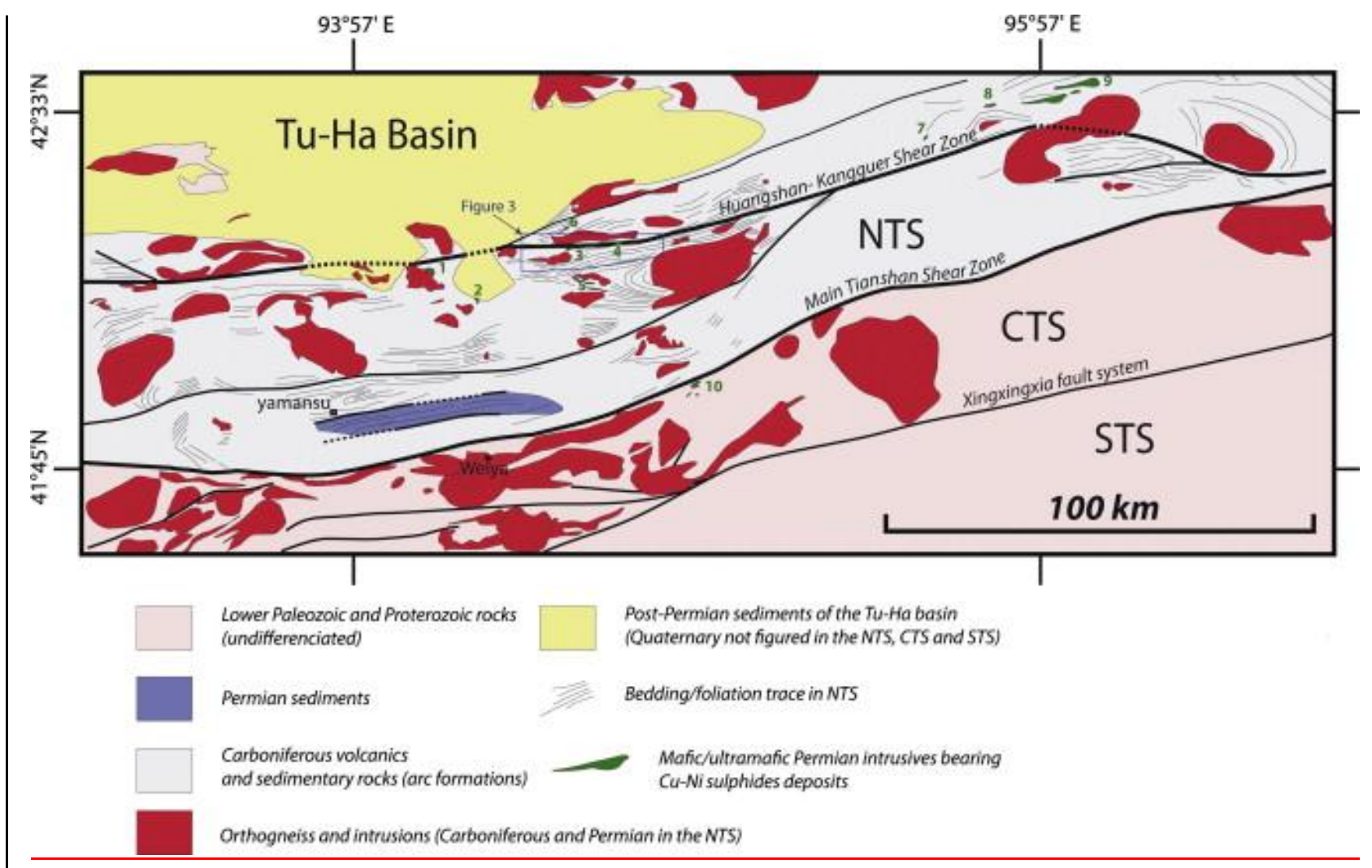

Figure 2: Geological and structural map of the eastern Tianshan (compiled and redrawn from Google Earth ${ }^{\mathrm{TM}}$ and geological map from XBGMR, 1992). NTS: North Tianshan domain; CTS: Central Tianshan domain; STS: South Tianshan domain. Localisation of Cu-Ni ( \pm PGE) sulphide deposits and occurrences of the eastern Tianshan ore belt: 1. Tudun; 2. Erhongwa; 3. Huangshanxi; 4. Huangshandong; 5. Huangshannan; 6. Xiangshan; 7. Tulu; 8. Tula'ergen; 9. Sidingheishan; 10. Baishiquan district. Inset corresponds to the Huangshan ore belt detailed in the Figure 3. 

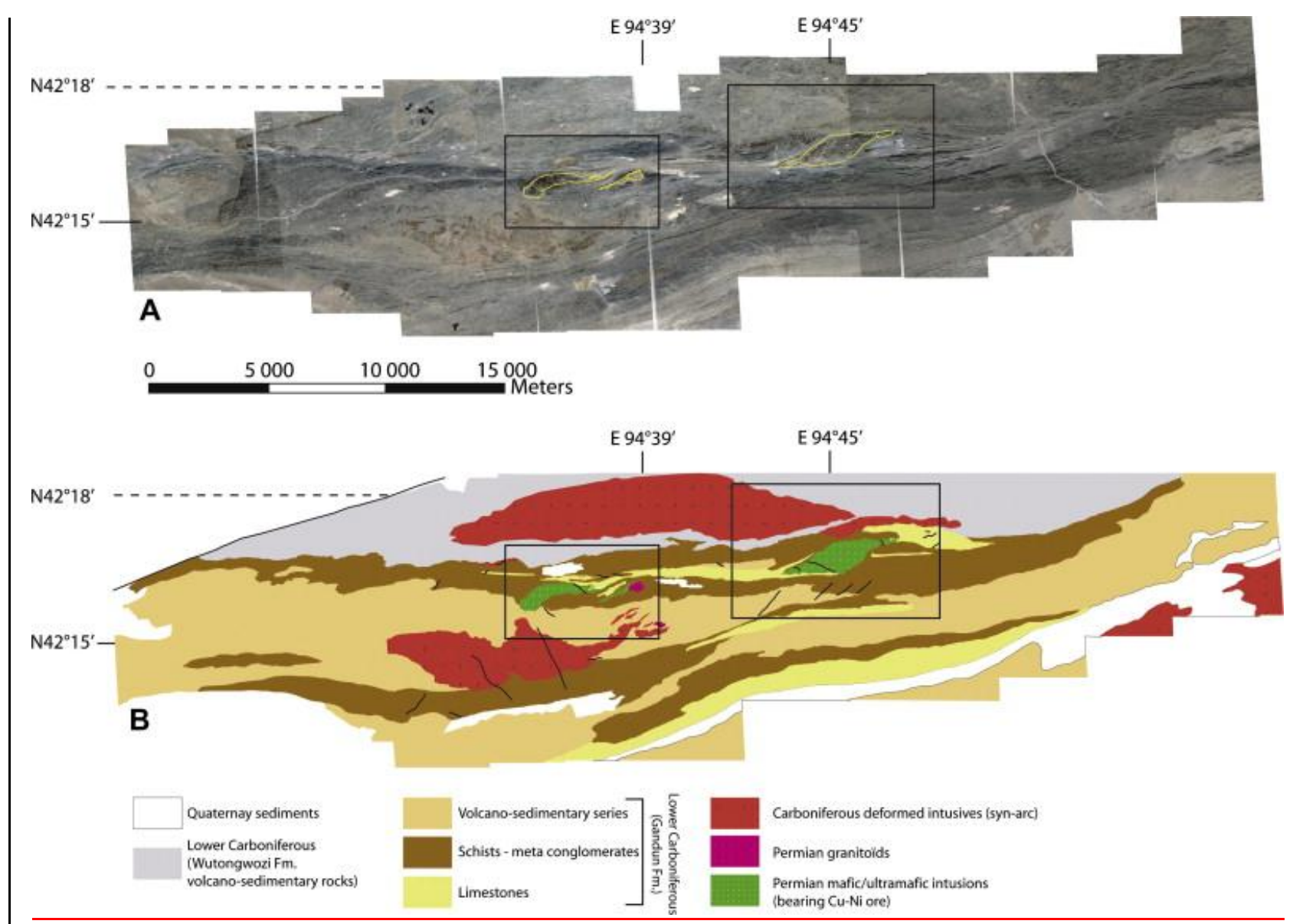

Figure 3: A) Satellite image from Google Earth ${ }^{\mathrm{TM}}$ of the Huangshan Ni-Cu ore belt. Permian mafic/ultramafic intrusions are contoured in yellow. The E-W-trending Huangshan-Kangguer shear zone is particularly well-exposed; B) Geological map constructed and compiled from our field works, high resolution satellite image and geological map from XBGMR (1992). The left and right insets correspond respectively to the Figures 4 and 5. 


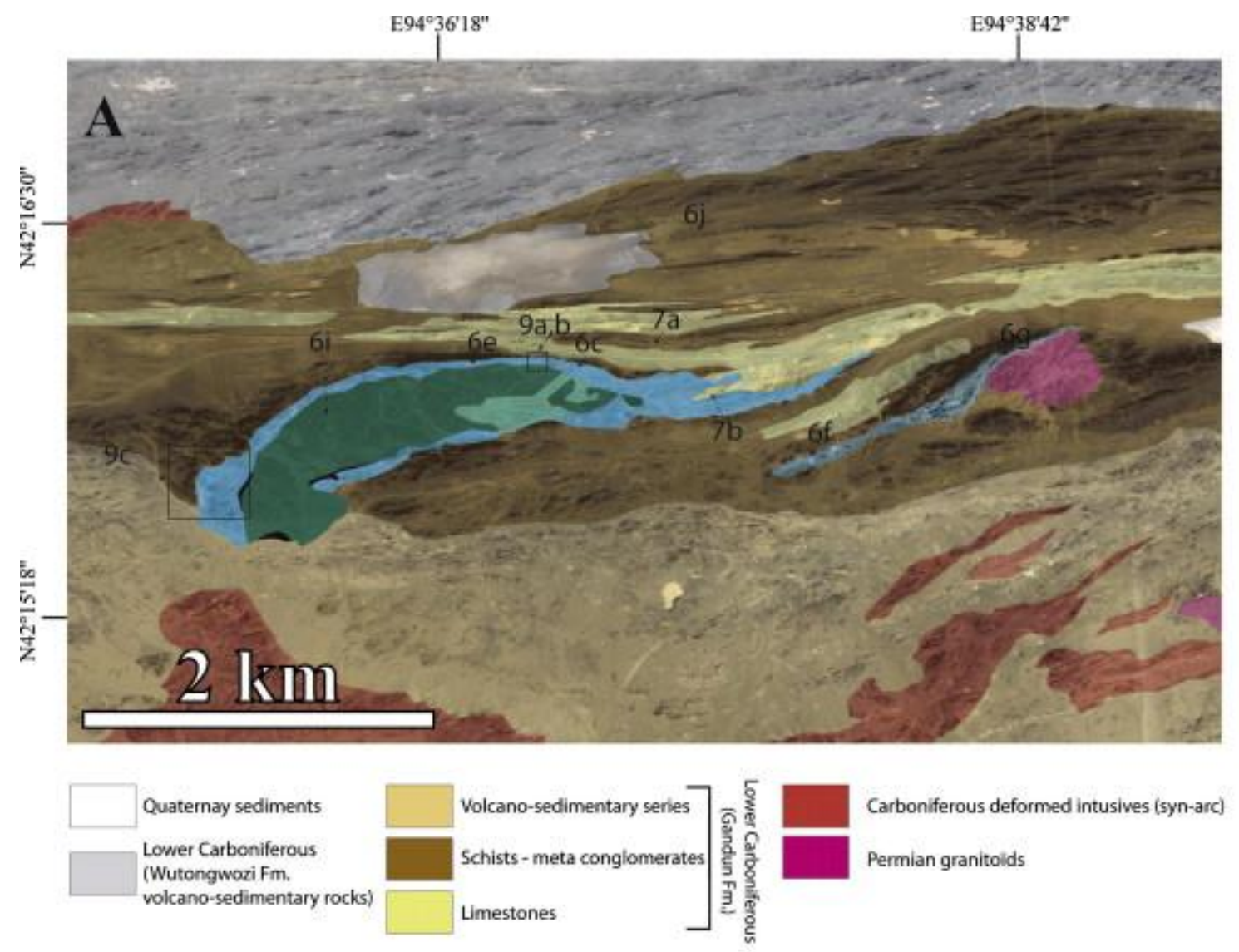

Permian mafic/ultramafic intusions (bearing Cu-Ni ore) :

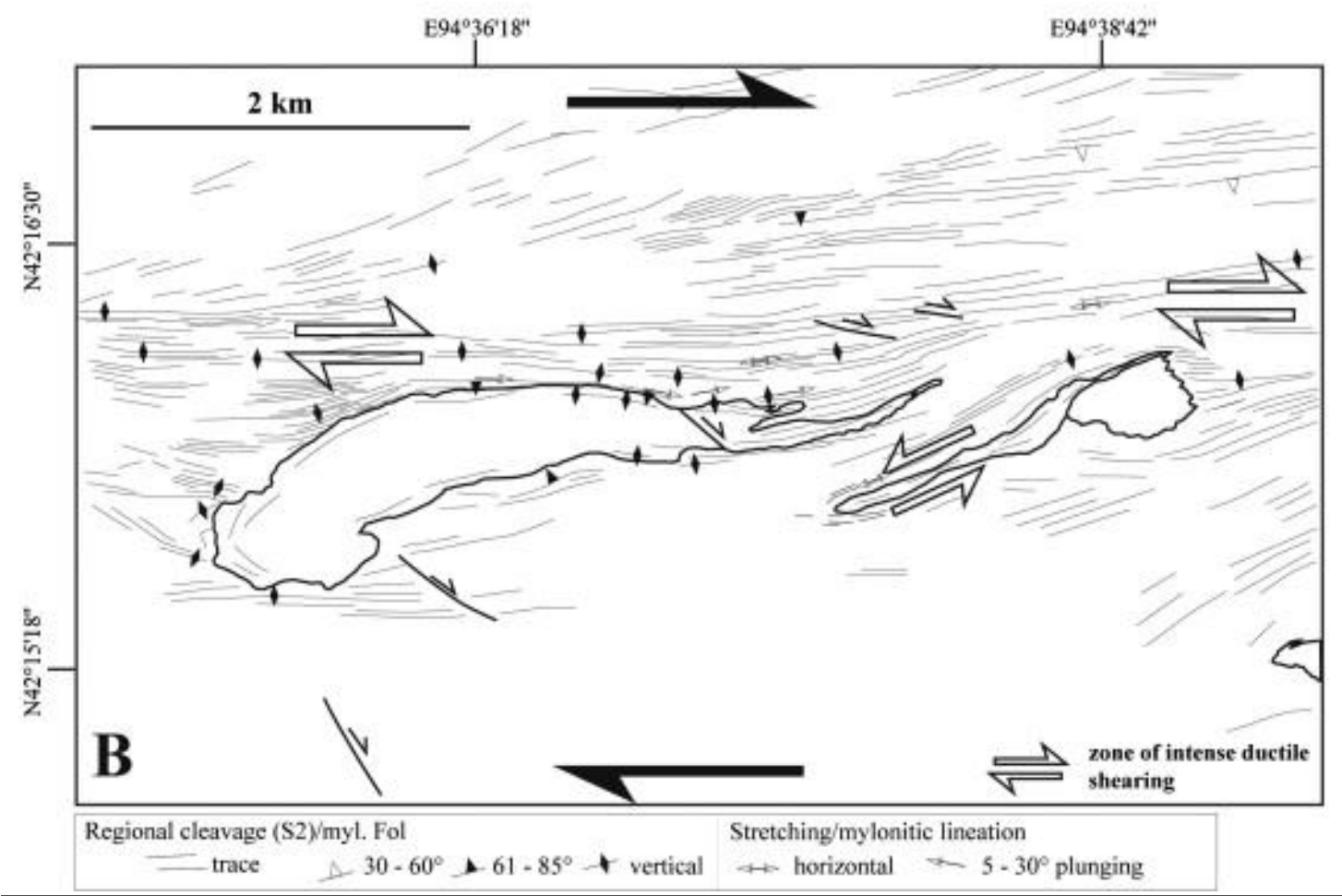


Figure 4: Geological and structural maps of the Huangshanxi intrusion, location Figure 3. A) Geological map draped on satellite image. Lithologies and contours have been remapped and re-interpreted from Li et al. (1989); B) Structural sketch from photo interpretation and field data. Black arrows indicate the bulk right-lateral sense of shear. 

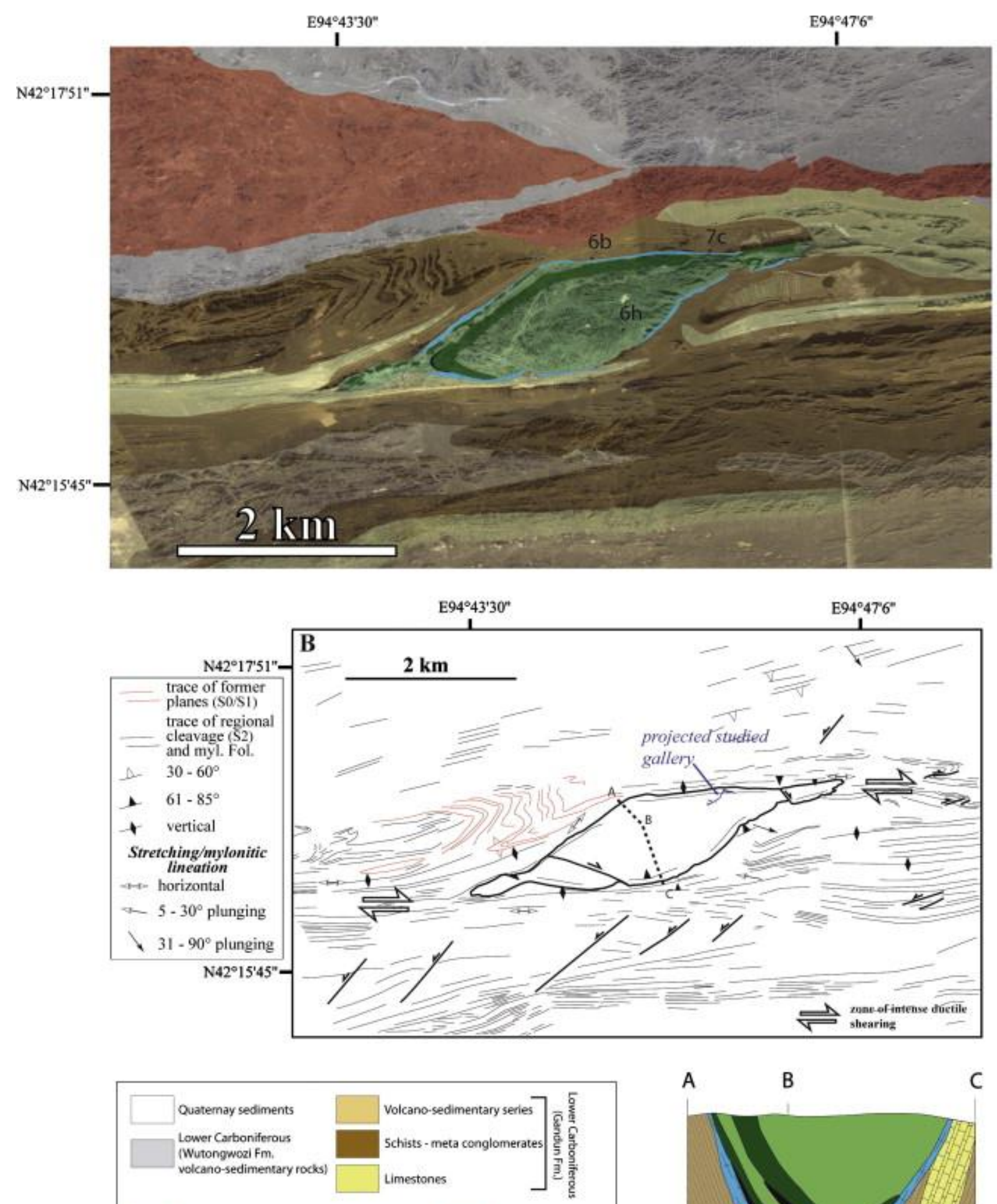

Carboniferous deformed intusives (syn-arc)

Permian granitoïds

Permian mafic/ultramafic intusions (bearing $\mathrm{Cu}-\mathrm{Ni}$ ore) :
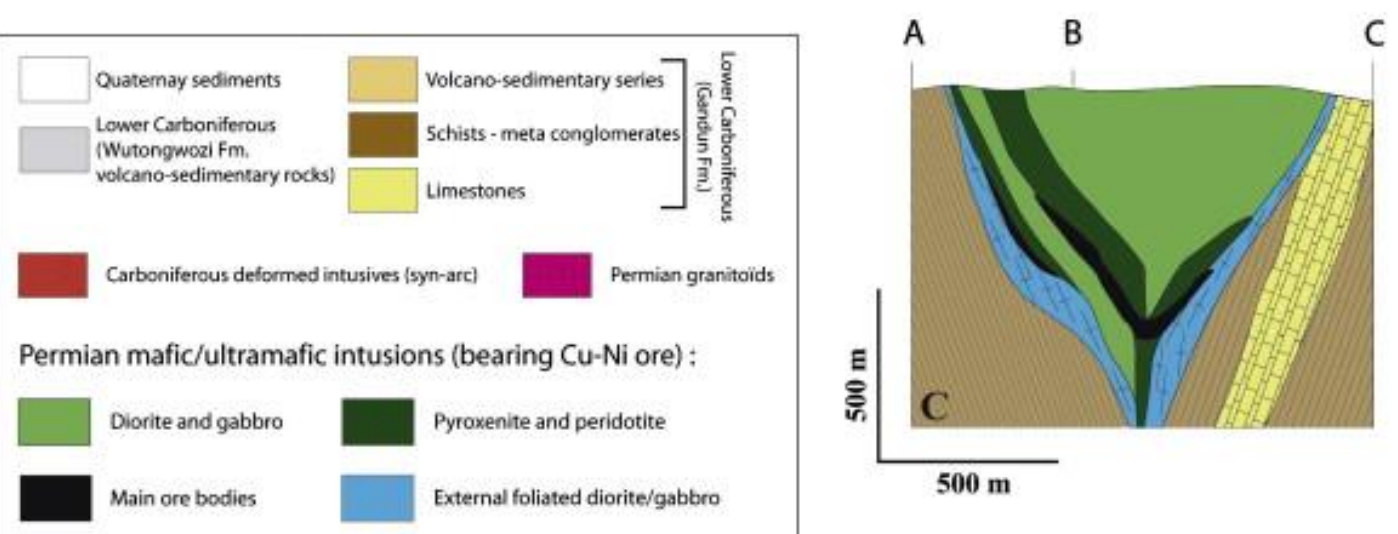

Figure 5: Geological and structural maps of the Huangshandong intrusion, location Figure 3.

A) Geological map draped on satellite image. Lithologies and contours have been remapped 
and re-interpreted from Li et al. (1989); B) Structural sketch from photo interpretation and field data; the sinistral NE-trending minor faults are interpreted as bookshelf antithetic faults in a bulk right-lateral shear of the area (see text for explanation); C) Cross-section through the Huangshandong intrusion. The funnel shape has been interpreted from numerous mine works (wells and galleries) compiled in Li et al. (1989). From our data, we have reinterpreted the internal structure and facies distribution. 

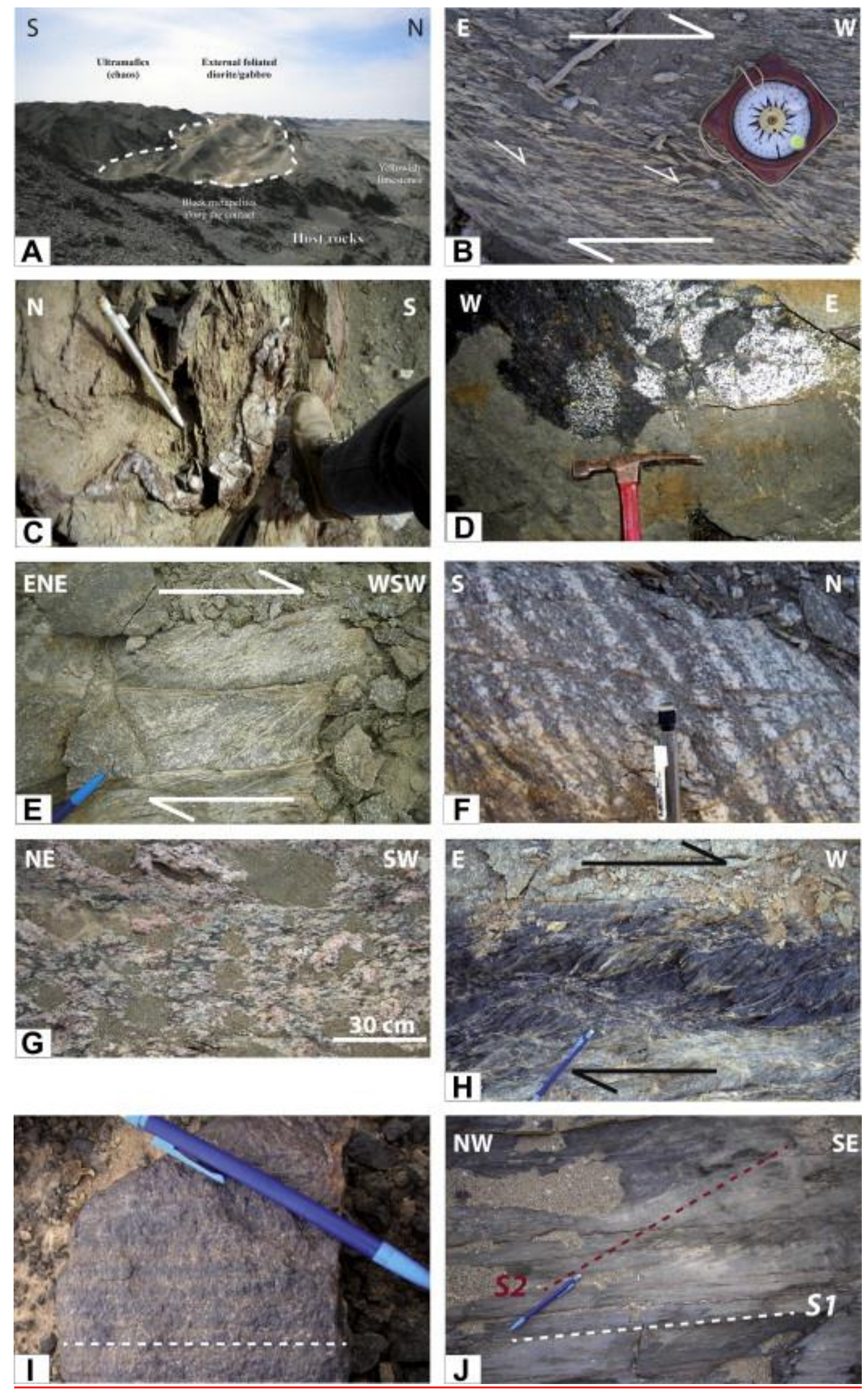

Figure 6: A) Northern contact of the Huangshanxi intrusion; B) Dextral C' shear bands affecting the external foliated diorite along the Huangshandong intrusion northern contact; C) 
The external foliated diorite along the huangshanxi intrusion northern contact. Quartz veins, folded with steeply-dipping axes, attest a large part of solid state deformation; D) Typical magmatic mingling contact between gabbroic (right side) and pyroxenite (left side) magma batches (Huangshandong intrusion, level $480 \mathrm{~m}$ ); E) dextral shear bands developed within the external foliated diorite of the Huangshanxi intrusion, northern contact; F) Layering developed within the small elongated diorite intrusion located between the two main intrusions. Amphibole and plagioclase layers alternates without any intracrystalline deformation. The layering is vertical and N65E-trending; G) Diffuse patch of pegmatoid within the same diorite. Amphiboles define a vertical N60E-trending mineral foliation; $\mathrm{H}$ ) Dextral near vertical shear bands developed within an internal gabbro of the Huangshandong intrusion. The gabbro is strongly deformed and altered in a dark fine grained epidote-chloritecalcite-actinolite ( \pm muscovite, tourmaline and iron oxides) assemblage, resulting from fluid flow channelized along the shear band; I) Hornblende peridotite from the Huangshanxi intrusion presenting artifact of layering: the planar fabrics correspond to a regular set of veinlets, in which fluids flew and were responsible for a pervasive alteration (biotite, actinolite, hematite, serpentine) of wallrocks. Location on Figure 4; J) Relationships between older S1 cleavage and syn-wrenching S2 cleavage. Location on Figure 4. 

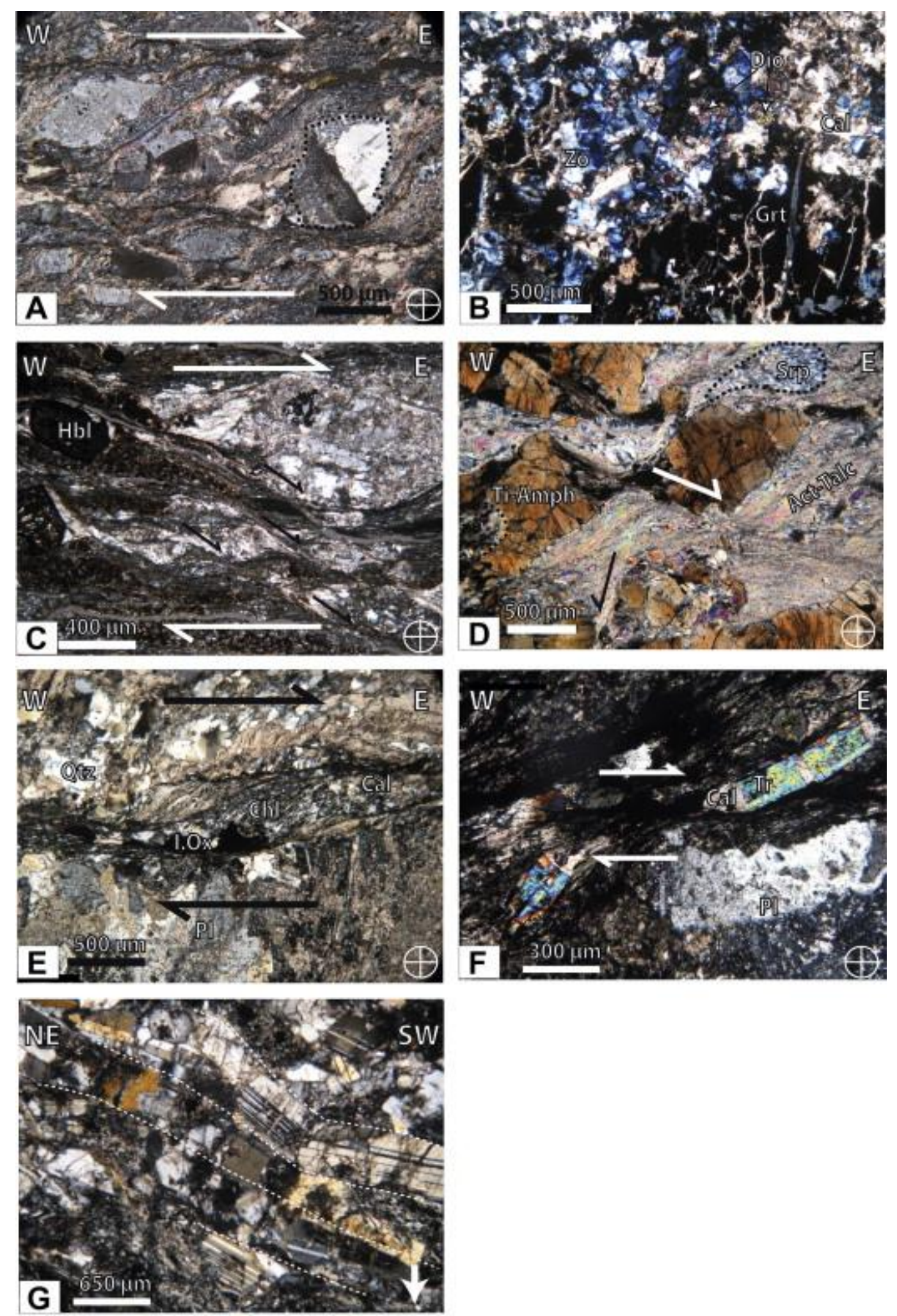

Figure 7: Thin sections photographs, all taken under crossed polars; gravity vector is indicated with arrow; A) Metagreywackes composed of quartz and feldspath clasts with a foliation marked by calcite-white mica and chlorite growth. Dextral shearing is evident, asymmetric 
calcite pressure shadows are developed around feldspath clasts (contoured with dashed line), see location Figure 4; B) Garnet-diopside-zoisite-titanite-calcite skarn assemblage developed in the contact aureole of the Huangshanxi intrusion, see location Figure 4; C) External foliated diorite facies, see location Figure 5. The diorite has suffered a strong carbonate-chlorite alteration associated with a bulk dextral shear evidenced by the mylonitic foliation and the C' shear bands (black arrows). Sparse magmatic hornblendes (Hbl) have been preserved; D) Sheared ultramafic rock, see location Figure 4. The rock has been metamorphosed in the greenschist facies with actinolite growth. Deformed and serpentinized olivine grain is contoured (dashed line), "intercumulus" Ti-rich amphiboles are partially preserved and enclosed poikilitacally rounded olivine crystals. Note the antithetic shear at the bottom; E, F) Sample from the outcrop Figure $6 \mathrm{H}$, see location Figure 5. Dextral shear bands within a gabbro. The deformation focuses a fluid flow responsible for a complete hydrothermal replacement of the gabbro by a chlorite-calcite-quartz-tourmaline-iron oxides (I.ox) assemblage. Muscovite, actinolite and epidote are also observed in other sections; G) Flat lying magmatic foliation defined by aligned plagioclases within a partially altered hornblende gabbro. The plagioclase crystals show no crystalplastic deformation (e.g. deformation twins, recrystallization...). Note the numerous calcite/quartz-filled fractures, see location Figure 8. 


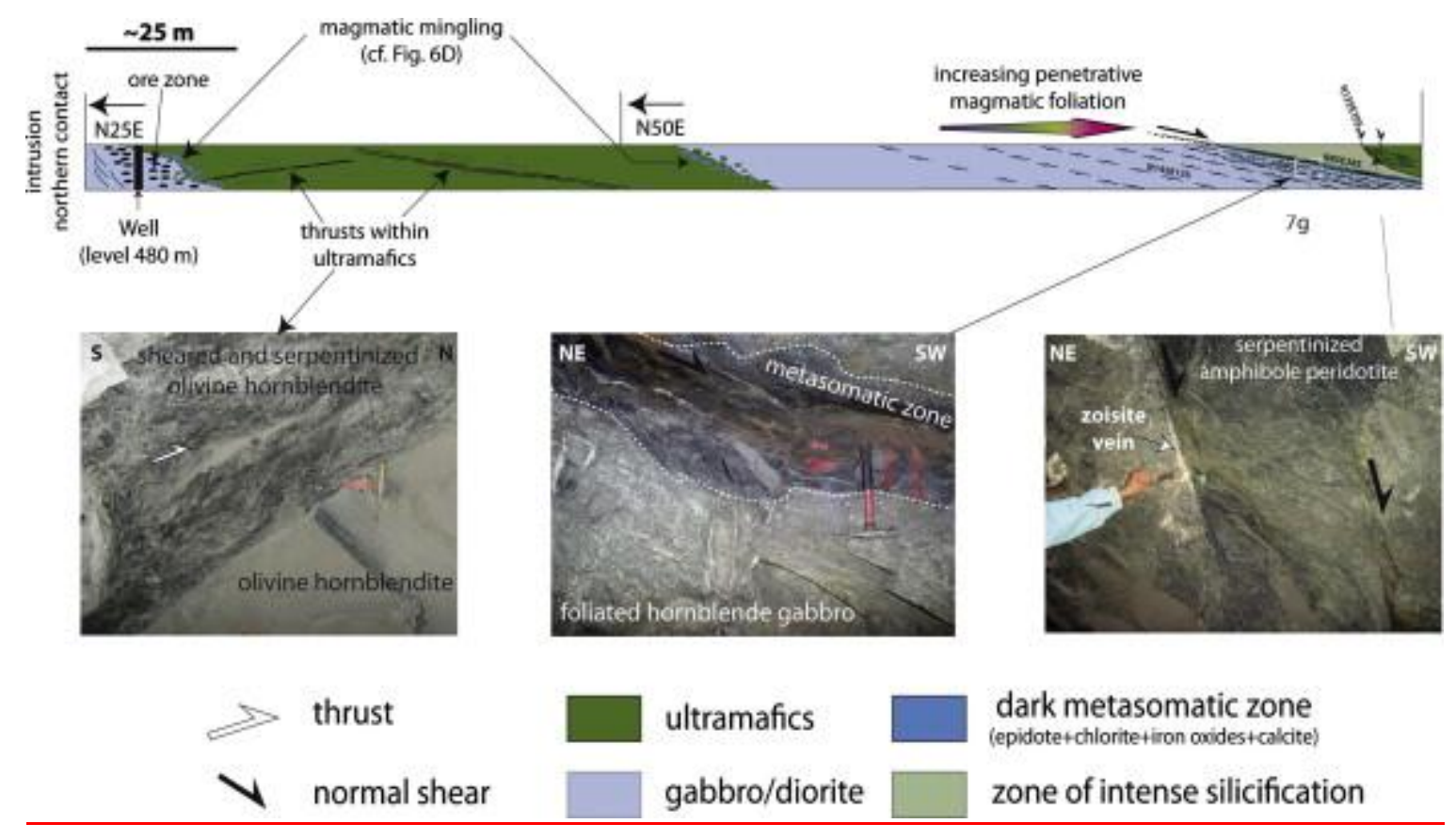

Figure 8: Structures within the Huangshandong intrusion from gallery mapping (location Figure 5). See text for explanation. 
A

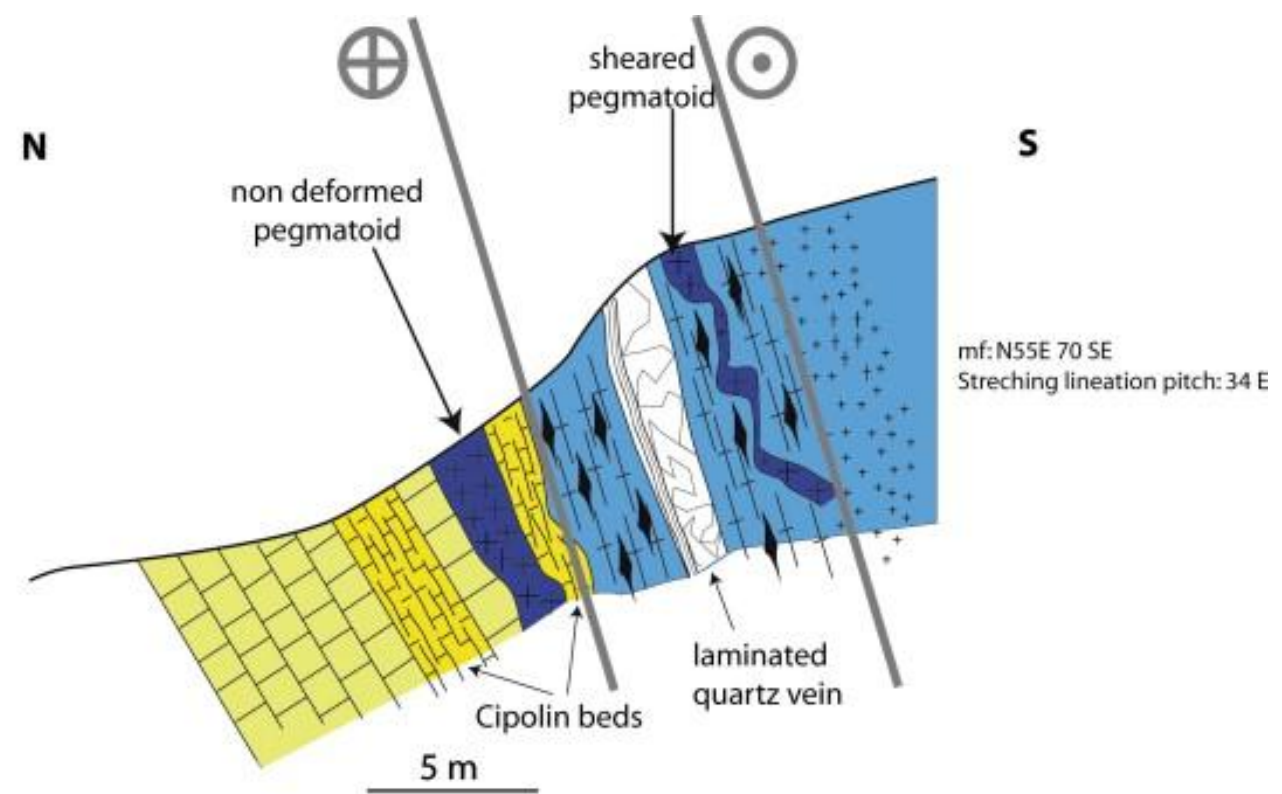

B

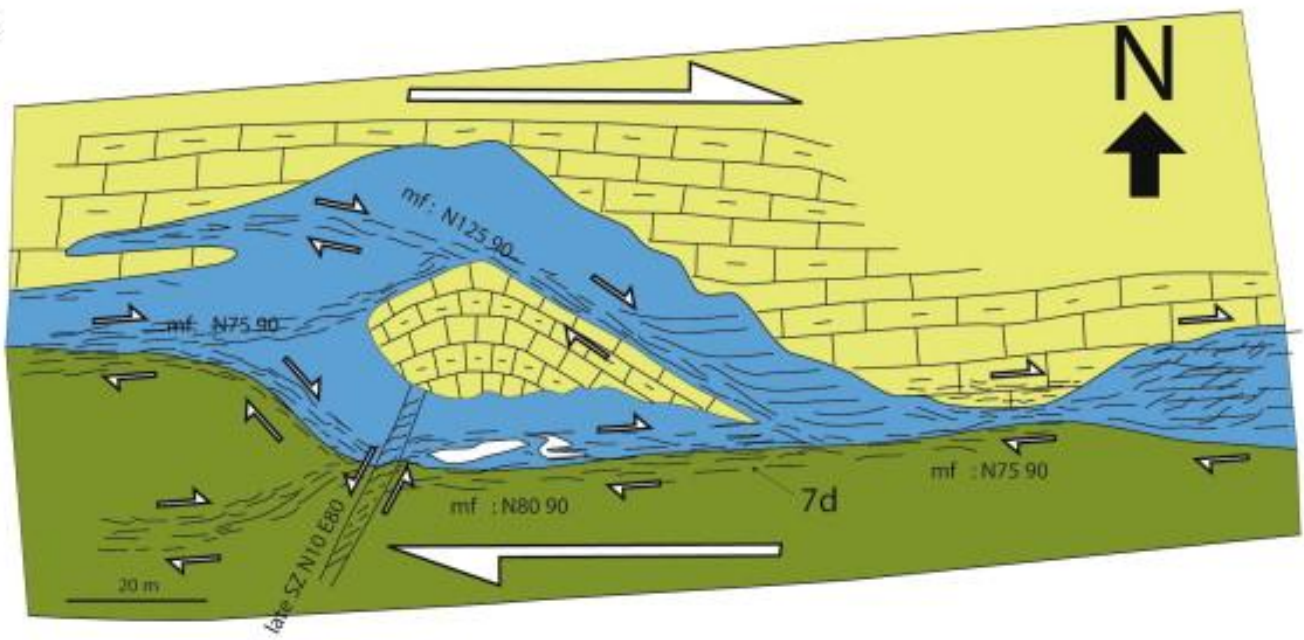

C

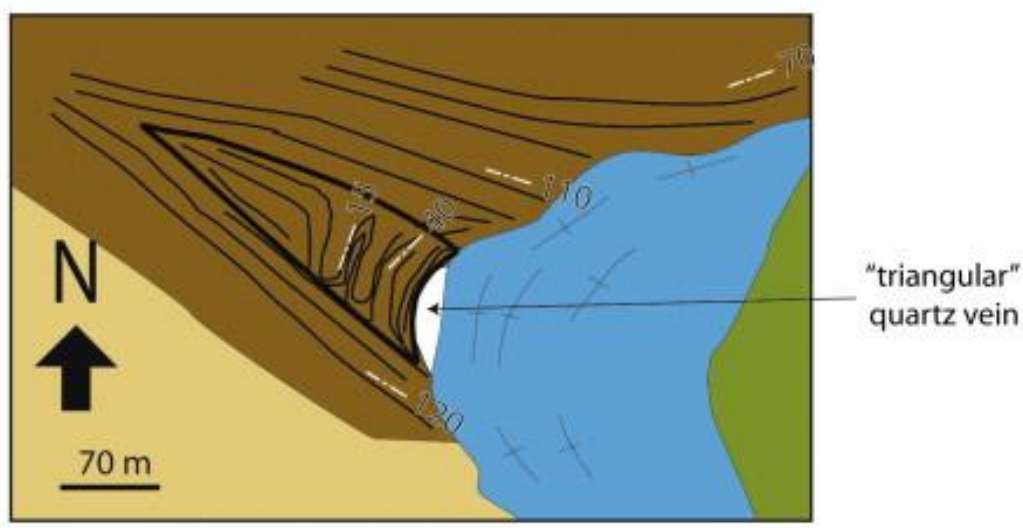
Volcano-sedimentary series
Schists - meta conglomerates
Limestones
Pyroxenite and peridotite
External foliated diorite/gabbro
mf: mylonitic foliation
Quartz and pegmatoild veins 
Figure 9: Contacts of the Huangshanxi intrusion. A) Cross section through the northern contact. Most of the dextral non coaxial deformation is accommodated within the external foliated diorite; B) Detailed map along the northern contact. At this place, the host rocks are limestones in yellow. The deformation is achieved through an anastomosing network of shear bands and mylonitic zones. Quartz veins are folded within the shear zone. Note the dextral pull-apart shape "filled" with the external diorite; C) The western contact shows a characteristic triple junction pattern associated with a triangular or saddle reef quartz vein.

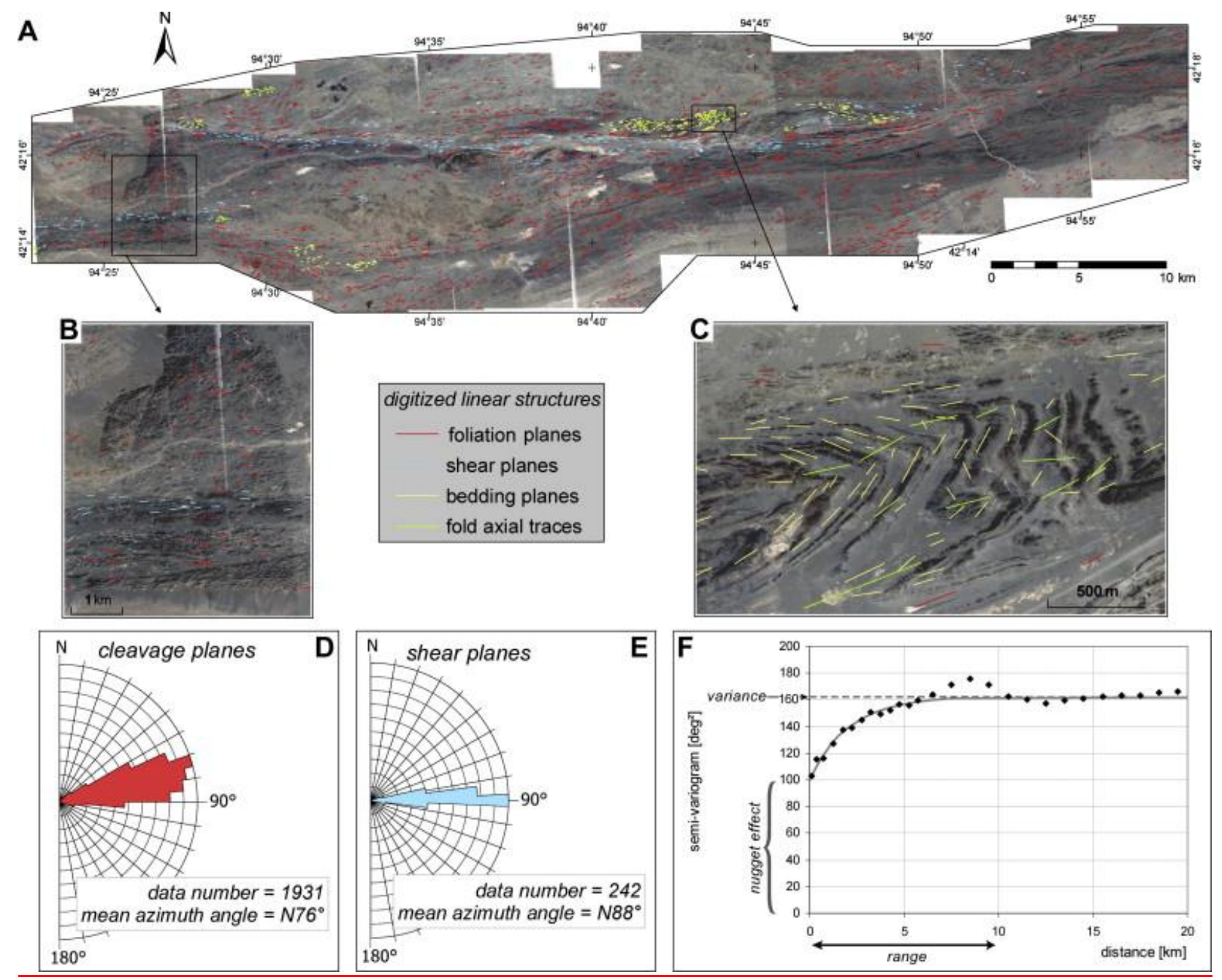

Figure 10: A) Mosaic of the satellite images used for the regional scale structural analysis of the Huangshan area (source: Google Earth, "Huangshan area.”). 2466 line segments have been digitized along the map trace of geological structures and correspond to: foliation planes 
in red, shear planes in blue, bedding planes in yellow and fold axis traces in green, B) Closeup view in the easternmost part of the map displayed in A) showing local obliquity in between foliation plane strike angles and shear plane ones. When considering subvertical structures and plane strain type deformation, such geometry argues for dextral simple shear deformation, C) close-up view in the Huangshandong area where folded stratification can be observed. Here, bedding planes are not transposed to the foliation's orientation; note that fold axial traces (in green) strike almost parallel to the trace of the foliation planes (in red), D) rose diagram of the azimuth angle values for foliation planes (also including 33 fold axial traces, see before). Bins range each $5^{\circ}$ angle and the maximum class value (outbound circle) is 150 counts. Note that azimuth angles show a normal type distribution around the mean $\mathrm{N}^{\circ} 6^{\circ}$ value, E) rose diagram of the azimuth angle values for shear planes (c planes). Bins range each $5^{\circ}$ angle and the maximum class value (outbound circle) is 42 counts, F) sample variogram of azimuth values for foliations and fold axial traces data. In map view, data points of this class have an average nearest neighbour distance of about 250 meters. In a way to better highlight potential spatial correlations at short distances, sample variogram (black dots) has been calculated for lag distances of: $250 \mathrm{~m}$ from 0 to $500 \mathrm{~m}$ distance, $500 \mathrm{~m}$ for 0.5 to $6 \mathrm{~km}$ and $1 \mathrm{~km}$ for inter-distance of up to $30 \mathrm{~km}$. An exponential model theoretical variogram (middle grey curve) has been fitted to the sample one with a nugget value of 100 square degrees and a sill adjusted at 162 square degrees, equal to the total variance value of the data set. The practical range value for this exponential function is of $6.2 \mathrm{~km}$ and the theoretical curve is well supported by sample variogram points up to this lag distance value. The "real" range value of this variogram corresponds here to $\sim 10 \mathrm{~km}$. 

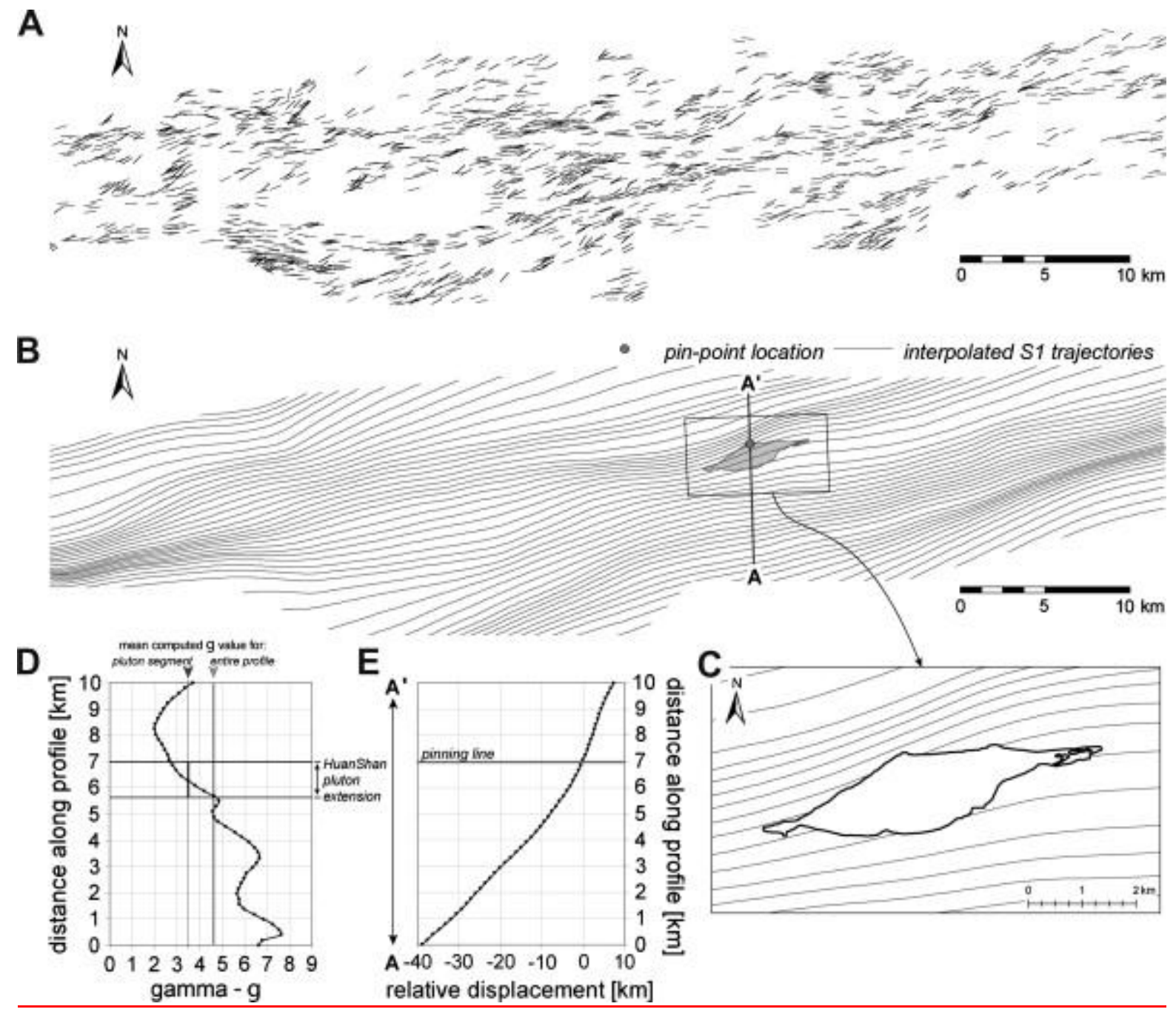

Figure 11: Model of interpolated foliation trajectories and shear strain computation throughout the Huangshan area; A) set of foliation directional data (including fold axial traces) used for interpolation of the trajectory map. Due to very good exposure conditions of the area, numerous (1931) data points can be digitized from the satellite image analysis and these are evenly spaced throughout the study zone, B) automatic foliation trajectories map drawn from the interpolated foliation azimuth values. Note that foliation's direction clearly show lateral spatial variations throughout the map; trajectories bend around the average $\mathrm{N}^{\circ} 6^{\circ}$ direction. Map boundaries of the Huangshandong intrusion are displayed on the map. Pin point used for finite deformation restoration is arbitrarily fixed to the northern tip of this massif, C) close-up view of the interpolated foliation trajectories around the Huangshandong. Trajectories display typical S shape geometry in this area, D) north-south fluctuation of the 
finite shear amount $\gamma$ along the A-A' profile (see location on map B), perpendicularly to the regional average shear direction (see Fig. 10e). $\gamma$ value is calculated from the obliquity angle in between average shear direction and local interpolated foliation direction (see text for further explanations). Along this profile, $\gamma$ ranges from 2.0 to a maximum of 7.6 in the southernmost part. At first order, the finite shear increases towards the south with second order variations at a few kilometres distance scale. The average calculated $\gamma$ value equals 4.6 for the entire profile and 3.5 for the segment which frame the Huangshandong intrusion, E) relative displacement parallel to simple shear direction; the displacement equals the product of $\gamma$ value and the distance perpendicular to the mean shear direction (i.e. along the profile). As a reference, a pinning line has been arbitrarily fixed along the northern edge of the intrusion (see Figure 11B for location).

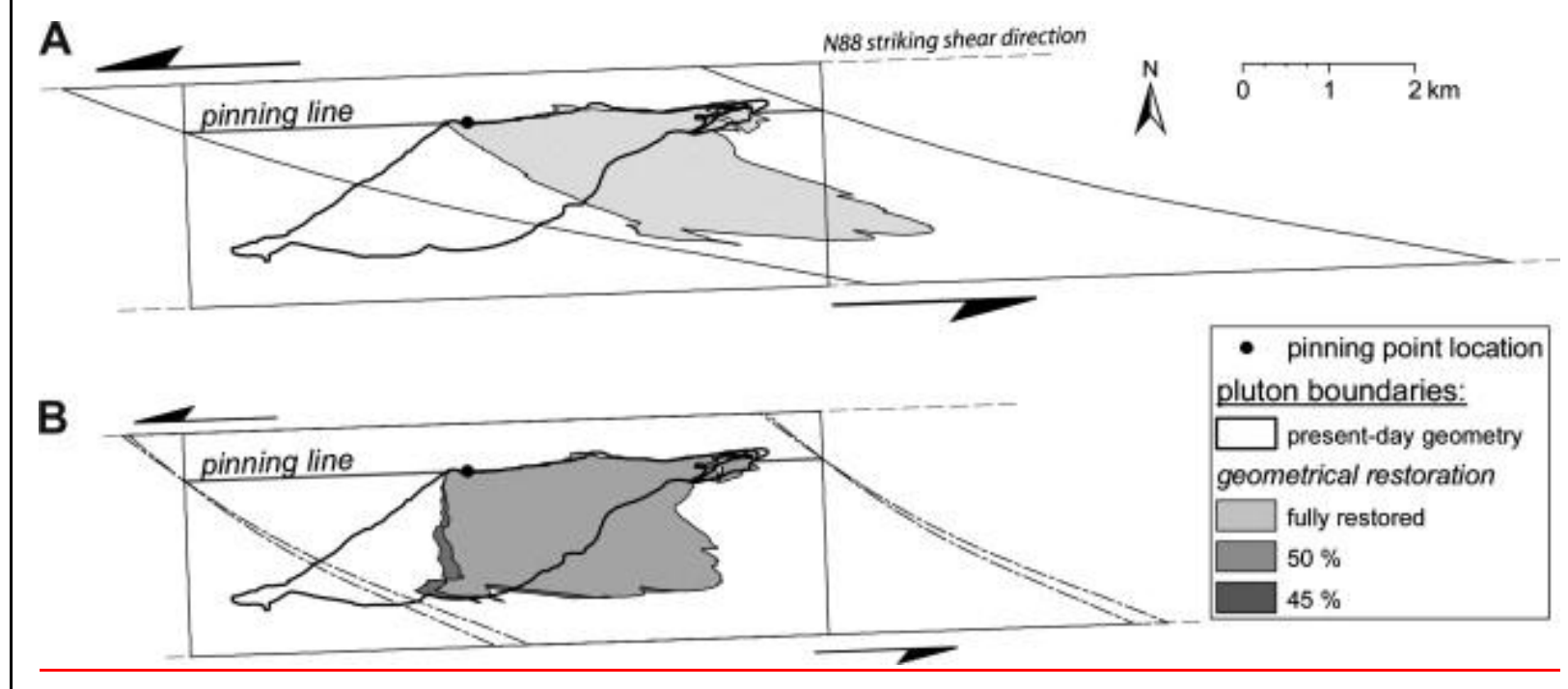

Figure 12: Model of simple shear restoration within the Huangshandong area. Shearing direction is given by the N88 average C planes striking angle (see Figure 10E); pinning line is arbitrarily fixed to the northern edge of the ultramafic intrusion; the total relative displacement value used for shearing inversion computation is given on figure $\mathrm{n}^{\circ} 11 \mathrm{E}$ (see profile A-A'). A) Restored state of the geological boundaries of the Hungshandong intrusion 
after removing the overall calculated shear strain amount (Figure 11D). Present-day shape of the intrusion's boundaries is displayed as thick black lines; B) shape of the Hungshandong geological boundaries after restoring $45 \%$ and $50 \%$ of the calculated total shear strain amount (Figure 11D). Note that the intrusion's boundaries display as isotropic, rectangle geometries after this partial simple shear inversion.

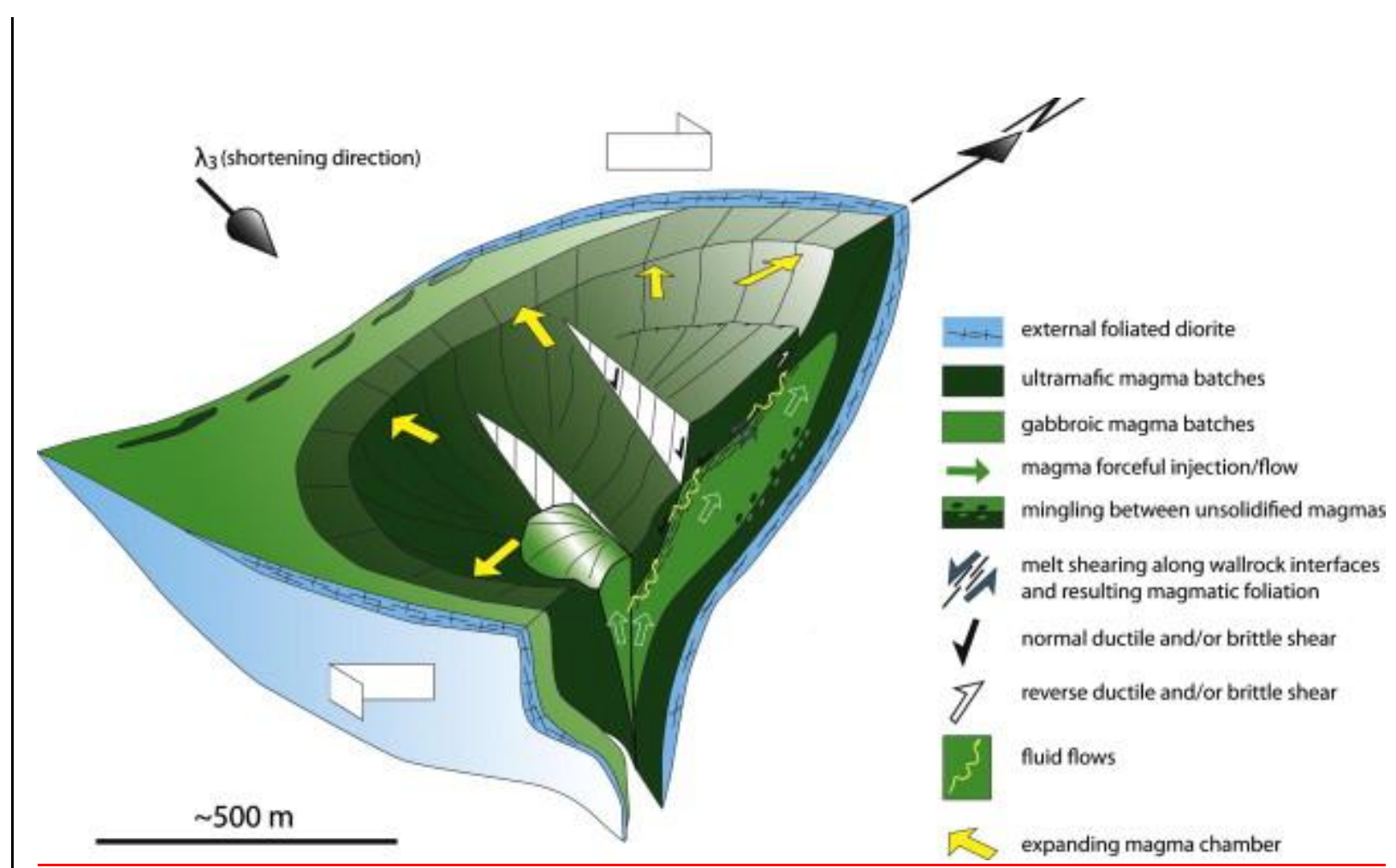

Figure 13: 3D reconstruction of the syntectonic Huangshandong mafic/ultramafic sheeted intrusion. Each magma batches emplaced through vertical NW-trending extensional fractures or normal fault. See text for further explanations. 


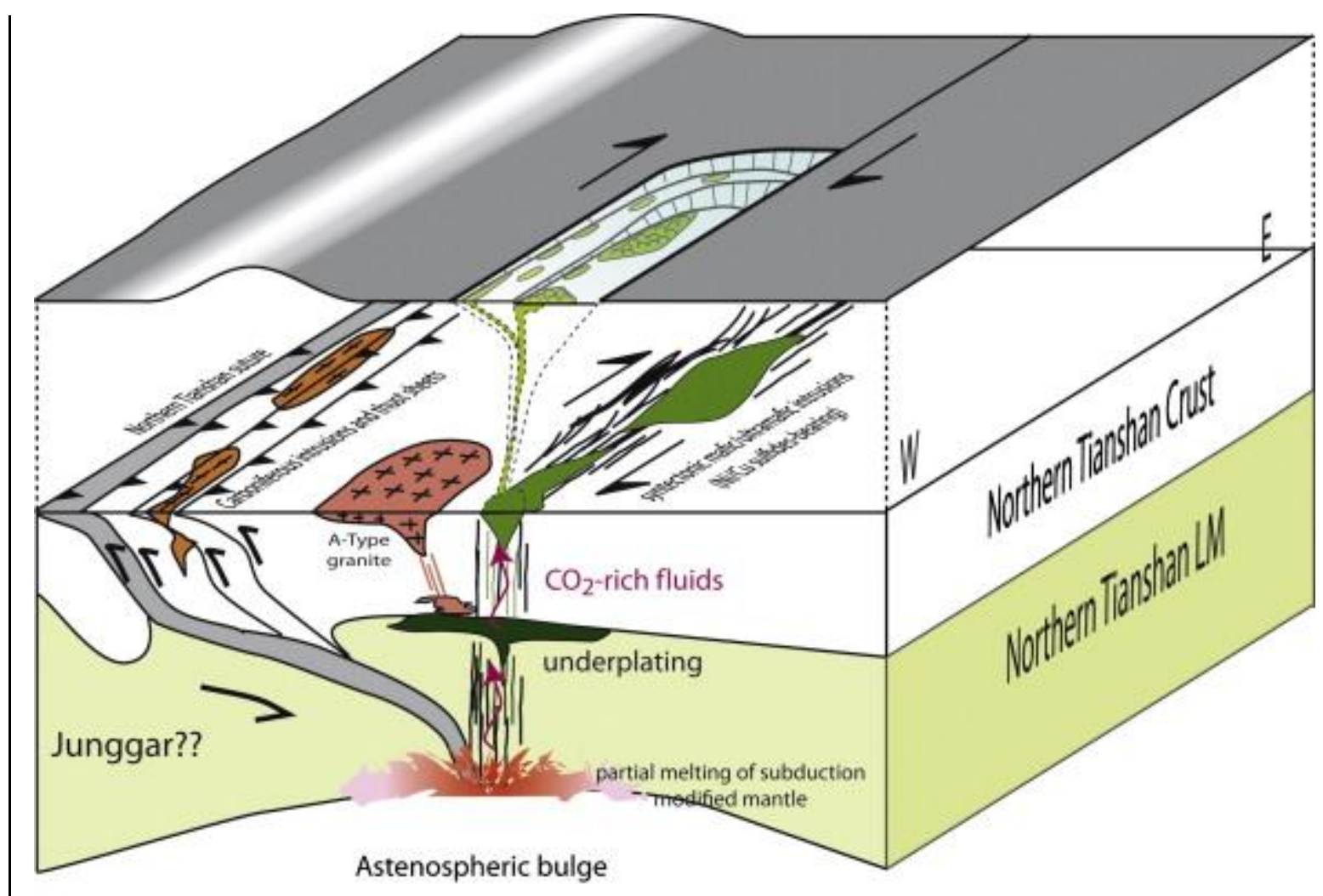

Not to scale

Figure 14: Schematic geodynamic model of the Early Permian wrenching in the Eastern Tianshan (around $270 \mathrm{Ma}$ ). The origin of the astenospheric bulge is unknown. See text for explanation. 